NBER WORKING PAPER SERIES

\title{
WAS IT STOLPER-SAMUELSON, INFANT INDUSTRY OR SOMETHING ELSE? WORLD TARIFFS 1789-1938
}

\author{
Jeffrey G. Williamson \\ Working Paper 9656 \\ http://www.nber.org/papers/w9656 \\ NATIONAL BUREAU OF ECONOMIC RESEARCH \\ 1050 Massachusetts Avenue \\ Cambridge, MA 02138 \\ April 2003
}

Paper to be presented at the Symposium Eli Heckscher 1879-1952: A Celebration, Stockholm (May 22- 24, 2003). This project has received superb research assistance from David Clingingsmith, Martin Kanz and István Zöllei. I have also benefitted by comments from Dick Baldwin, Gerry della Paolera, Graciella Marquez, Richard Cooper, Toni Estevadeordal, Ron Findlay, Jeff Frieden, Steve Haber, Elhanan Helpman, Doug Irwin, Ed Leamer, Stephen Meardon, José Manuel Ocampo, Leandro Prados, Dani Rodrik, Dick Salvucci, Ken Sokoloff, Alan Taylor, Daniel Waldenström and participants at the Harvard Economic History Workshop (February 1, 2002), the Conference on the Political Economy of Globalization (Dublin, August 29-31, 2002), the Economic History Association Meetings (St. Louis, October 11-13, 2002), the FTAA and Beyond Conference (Punta del Este, December 15-16, 2002), and the RIN Conference (Punta del Este, December 17-19, 2002). Most important, this paper draws extensively on a tariff project which has involved previous papers with four collaborators: Luis Bértola (Universidad de la Republica), Chris Blattman (Berkeley), John Coatsworth (Harvard), and Michael Clemens (Center for Global Development). I am grateful to all of them, but errors remaining belong to me. I also acknowledge generous financial support from the National Science Foundation SES-0001362. The views expressed herein are those of the authors and not necessarily those of the National Bureau of Economic Research.

C2003 by Jeffrey G. Williamson. All rights reserved. Short sections of text not to exceed two paragraphs, may be quoted without explicit permission provided that full credit including Cnotice, is given to the source. 
Was It Stolper-Samuelson, Infant Industry or Something Else? World Trade Tariffs 1789-1938 Jeffrey G. Williamson

NBER Working Paper No. 9656

April 2003

JEL No. F1, N7, O1

\begin{abstract}
$\underline{\text { ABSTRACT }}$
This paper uses history to explore the empirical content of two determinants of tariff policy that have a long pedigree: the Stolper-Samuelson corollary to the Heckscher-Ohlin theorem, and the infantindustry argument for protection. It reports a set of world tariff facts for the 150 years between 1789 and 1938 that have not been well appreciated. First, tariff rates varied enormously around the globe with high tariff regions including the United States, Latin America, and industrially-lagging Europe, and the low tariff regions including Asia and the European industrial leaders. Second, while tariff rates rose on the European continent after the 1870s, they rose far more steeply and earlier in Latin America and industrially-lagging Europe, and more steeply even in Asia. Furthermore, after world tariff rates rose between 1865 and 1900, they then fell by half between 1900 and 1920, before tripling between 1920 and 1934. The most popular explanations for these world tariff facts come from two sources: Stolper-Samuelson -- scarce factors should lobby for protection when exposed to more intense world competition, and scarce factors should win the political battle if their votes carry heavy weight; and national industrial policy -- since late 20th century ISI policies must surely have their roots in the 19th century infant industry arguments. Looking at the same history that Eli Heckscher and Bertil Ohlin did to produce their famous theorem, or that Alexander Hamilton and Frederick List did to produce their equally famous infant industry argument, I find that latter is pretty much irrelevant until the 20th century, while the former starts playing an important role a little earlier when global forces open up in the 19th century. Throughout the 150 years, tariff policy was driven consistently (and often more importantly) by revenue needs and strategic tariff behavior. Geography, home market size, world economic environment, trading partner behavior, gunboats and tariff autonomy all mattered. So did Stolper-Samuelson.

Jeffrey G. Williamson

Department of Economics

Harvard University

Cambridge MA 02138

and NBER

jwilliam@kuznets.harvard.edu
\end{abstract}




\section{Thinking about Tariffs}

What determines tariff policy? It can't be conventional economics, since every mainstream economist agrees that free trade is a good thing (Smith 1776; Mill 1909; Krugman 1996; Bhagwati 2000a, 2000b). Yet, the politics of free trade have been surrounded by controversy ever since Alexander Hamilton tried shoving his protectionist policies down the throats of a new United States federal congress after 1789, and since Robert Peel ruined his political career by shoving free trade down the throats of the British Parliament in 1846. Political leaders have never been solely, or even largely, interested in maximizing national income, let alone maximizing world income, and "if this means sacrificing the overall size of the pie in order to get a larger slice for their supporters, then they will make the sacrifice" (McGillivray et al. 2001: p. 2). Protection and free trade have always been for sale in the political market place (Grossman and Helpman 1994), but having said so doesn't make the question -what determines tariff policy? - much easier to answer. After all, nations will adopt different tariff policies to the extent that there are different economic interests lobbying for those policies, to the extent that the economic environment impacting on those interests is different, and to the extent that different political institutions dictate which economic interests have the most votes.

Thus, to answer the question - what determines tariff policy? - we need to understand the underlying economic, political and institutional fundamentals at work. As a recent book collaboration by four political scientists has pointed out so effectively (McGillivray et al. 2001: pp. 3-16), there are three ways that endogenous tariff theory has confronted fact as it has sought to uncover the fundamentals. First, since tariffs vary by commodity traded, one way to uncover the fundamentals is to explore the determinants of that within-country industry variation. Second, since tariffs vary by country, we can learn about the fundamentals driving endogenous tariffs by comparing countries at various points in time. Third, tariffs vary over time, offering us another way to identify those fundamentals. It is fair to say that 
the vast majority of the empirical work on endogenous tariffs has elected the first route -- within-country variance across industries, and most of it is on the post-World War II US, making it impossible to identify the role of world economic environment and political institutions (e.g. Magee, Brock and Young 1989; but for pre-World War II United States, see Pincus 1977, and Marvel and Ray 1983, 1987). The second route - variance across countries - has been exploited less intensively (e.g. Kindleberger 1951; Conybeare 1983; Magee, Brock and Young 1989; Bates, Brock and Tiefenthaler 1991). The third route variance over time - has been exploited the least (e.g. Magee, Brock and Young 1989). A fourth route could be added to the list -- panel data, a route that has been explored comprehensively only very recently (Coatsworth and Williamson 2002; Blattman, Clemens and Williamson 2002; Clemens and Williamson 2002). This essay will exploit the second, third and fourth routes by first exploring quantitatively annual tariff rate data for 35 countries between 1865 and 1938 (accounting for 82.8 percent of the world's 1900 population), and second, exploring qualitatively the early experience of new nations - the United States after 1789, the new Latin American republics after the 1820s, and the emerging German Zollverein after 1818.

The next section will review the world tariff evidence 1865-1938, identifying the tariff facts most needing explanation. Section 3 explores the familiar Stolper-Samuelson corollary and its recent extensions, showing why it is so important to find out whether it has been the central force driving tariffs in the past. Section 4 does the same for the infant industry argument. Section 5 lays out the contending determinants of tariff policy, while section 6 explores their role empirically. Here, world tariffs are treated as country and time fixed effects between 1870 and 1938, a period that contains both the first global century up to World War I and the interwar autarkic disaster that followed. I find that tariff policy over those important seven decades was not driven primarily by infant industry, but rather by other forces, primarily Stolper-Samuelson, revenue needs and strategic tariff behavior. Section 7 confirms these econometric conclusions by looking at the qualitative experience of new nations in the late $18^{\text {th }}$ 
century and in the first half of the $19^{\text {th }}$ century, experience that has given us such phrases as "the infant industry argument" and "de-industrialization fears." For these young countries, however, revenue needs dominated tariff behavior.

\section{World Tariffs 1865-1938: What Facts Need to Be Explained?}

This essay uses the computed average tariff rate ${ }^{1}$ to explore the policy experience of 35 countries the world around between the 1860s and World War II: the United States; 3 members of the European industrial core (France, Germany, United Kingdom); 3 non-Latin European offshoots (Australia, Canada, New Zealand); 10 from the industrially-lagging European periphery (Austria-Hungary, Denmark, Greece, Italy, Norway, Portugal, Russia, Serbia, Spain, Sweden); 10 from Asia and the Mideast (Burma, Ceylon, China, Egypt, India, Indonesia, Japan, the Philippines, Siam, Turkey); and 8 from Latin America (Argentina, Brazil, Chile, Colombia, Cuba, Mexico, Peru, Uruguay). Figure 1 plots average world tariffs from the 1860 s to the 1990s, and Figure 2 plots it up to 1938 for some regional clubs. ${ }^{2}$ There are six regions plotted in Figure 2 - the US, the European industrial core, the European periphery, the European non-Latin offshoots, Asia and Latin America - the country members of which have just been identified.

Note first the powerful role played by inflations and deflations at key points in the past. Import duties were typically specific until modern times, quoted as pesos per bale, dollars per yard, or yen per ton. Under a regime of specific duties, abrupt changes in price levels can change import values in the

\footnotetext{
1 The average tariff rate is measured here as the share of customs revenues (import duties only) in total import values. It is part of the Williamson Tariff Project data base, used with collaborators in a series of papers (Bértola and Williamson 2003; Clemens and Williamson 2001, 2002; Coatsworth and Williamson 2002; Blattman, Clemens and Williamson 2002).

${ }^{2}$ I have also calculated (but do not report here) weighted tariff averages for the regional clubs in Figure 2, where weights are the country's total export share in regional exports or its GDP share. However, I prefer to treat countries as independent policy units regardless of size.
} 
denominator, but not the legislated duty in the numerator, thus producing big percentage point changes in equivalent ad valorem tariff rates. The impact of inflation during World War I was quite spectacular, and it had nothing to do with policy. Thus, tariff rates in all six regions fell sharply between 1914 and 1919 , and part of the rise in tariffs immediately after the war was also due to post-war deflation and the partial resumption of prewar price levels. The price deflation after 1929 was even more spectacular, and it too served to raise tariff rates at least on duties that were still specific (import values now declining). The specific-duty impact will be explored more systematically in section 6 , but it turns out that while the impact certainly played a role world wide at these critical points, it was not an important factor in accounting for differences between countries or for long run trends.

Second, the well-known surge to world protection in the 1920s and 1930s is certainly revealed in Figure 1. What is less well known, however, is the pronounced protectionist drift worldwide between 1865 and about 1900. And what looks in Figure 1 like a modest pre-World War I anti-globalization backlash -- a retreat from the liberal pro-global trade positions in mid-century (Williamson 1998; 2002) -is far more dramatic when the world averages are disaggregated in Figure 2. Indeed, there is a very pronounced rise in tariffs across Latin America, across the non-Latin European offshoots (the United States being the major exception) and across the European periphery. This steep rise up to the 1890s in the periphery's tariff rates far exceeds that of the European core, a notable fact given that so much has been written on the European continent's globalization backlash, while almost nothing has been written on globalization backlash in the periphery.

Third, note the enormous variance in levels of protection between the regional averages. The richer new world European offshoots had levels of protection almost three times that of the European core around the turn of the last century. When the US is shifted to the rich European offshoot club, the ratio of European offshoot tariffs to that of the core is more than three to one. To take another example, in 1925 the European periphery had tariffs about two and a half times higher than those in the European 
part of the industrial core. To take yet another example, in 1885 the poor but independent parts of Latin America (Brazil, Colombia, Mexico and Peru) had tariffs almost five times higher than those in the poor and dependent parts of Asia (Burma, Ceylon, China, Egypt, India, Indonesia and the Philippines), while the poor but independent parts of Asia (Siam, Turkey and Japan) had tariff rates about the same as the poor but dependent parts of Asia. Of course, colonial status, lack of autonomy and "unequal treaties" all played an important role in Asia, and we will want to control for that fact in what follows.

Fourth, there was great variance within these regional clubs. In 1905, tariffs in Uruguay (the most protectionist land-abundant and labor-scarce country) were about two and a half times those in Canada (the least protectionist land-abundant and labor-scarce country). In the same year, tariffs in Brazil and Colombia (the most protectionist poor but autonomous countries in Latin America) were almost ten times those in China and India (the least protectionist poor and non-autonomous countries in Asia). The same high-low range appeared within the industrial core (the United States five times the UK) and the European periphery (Russia six times Austria-Hungary). Between 1919 and 1938, the tariff variance between countries was about the same as tariff variance over time, but between 1865 and 1914, the tariff variance between countries was more than twice that of the tariff variance over time. Thus, explaining differences in tariff policy between countries is at least as challenging as explaining changes in tariff policy over the eight decades after the 1860 s, perhaps more so.

The empirical analysis later in this essay will treat countries as the unit of observation, but for a moment let us linger a little longer on the regional clubs. Prior to World War I, tariffs were much higher in the rich European offshoots than anywhere else. Furthermore, and as I have already mentioned, they would have been even higher had I allocated to this club one of the most protectionist, the United States (which is allocated instead to the core). ${ }^{3}$ The European members of the industrial core (France,

\footnotetext{
${ }^{3}$ The United States has always presented a problem to historians and economists alike. The canonical frontier economy with scarce labor and abundant resources, by 1900 it was also the world's industrial leader (Wright 1990) and a central market for the exports from the rest of the world, especially Latin America. So, while the United States
} 
Germany, UK) had the lowest tariffs, although the United States serves to raise the club average. Most members of the poor periphery in Asia were colonies or quasi-colonies of the industrial core (Burma, Ceylon, Egypt, India, Indonesia, the Philippines), or were forced to sign free trade agreements ("unequal treaties") with the core since the latter had naval guns trained on their potential trading partners (China, Japan), or viewed nearby gunboats as a sufficient threat to go open on their own (Siam). Thus, tariff rates in Asia were pretty much like those of the core early on, but they started drifting towards protection after the 1880s, long before the post-World War II independence movement.

It should also be stressed that colonial status did not necessarily imply lack of local influence on tariff policy. There are five colonies in our sample from Asia: Burma, Ceylon, India, Indonesia and the Philippines, although foreign influence was strong enough (including occupation) to make Egypt behave like a colony. A previous paper (Clemens and Williamson 2002) has shown that while colonial tariff policy did indeed mimic that of their masters, local conditions mattered as well. Thus, I retain the full sample of 35 in all that follows, although I will take care to control for colonial status and tariff autonomy.

In any case, while Asia had the lowest tariffs in 1865, they were approaching that of the protectionist rich European offshoots by 1914. The European periphery leaped to high levels of protection after the 1870s, with Russia leading the way (along with Greece and, to a lesser extent, Serbia). There is plenty of evidence of rising world protection before World War I (the unweighted average in the full sample rising from about $12 \%$ in 1865 to about $17.5 \%$ in 1900), and this drift towards more protection appeared everywhere except in an industrial core that includes the United States. The industrial core plotted in Figure 2 excludes the United States, but the much-studied continental backlash plotted there looks pretty modest compared with the rest of the world. Still, the pre-1914 global backlash took place mainly in the European offshoots (excluding the United States, which retreated from its

was certainly a rich European offshoot, I allocate it to the industrial core. 
enormous Civil War tariffs) and the European periphery. We also know who was leading the backlash in the 1870s and 1880s: Columbia and Russia were way ahead of the pack, with tariff rate increases of 20 percentage points or more; other backlash leaders with 5 to 12 percentage point increases were Argentina, Canada, Chile, New Zealand and Uruguay - all rich European offshoots, plus a regional mixture containing Egypt, Greece, and Peru, as well as some European continentals who just barely make it over the 5 percentage-point-increase bar -- France, Germany, Italy, Portugal and Spain. ${ }^{4}$ There is also evidence of a worldwide reversal in the pre-war drift towards protection after about 1900, but even then important parts of the periphery bucked the liberal tide (e. g. Brazil, Colombia, Japan and the Philippines).

There are some surprises in these tariff data that have not been noticed by those scholars who have concentrated on one region or even on just one country. For example, the traditional literature written by European economic historians has made much of the tariff backlash on the continent to the "grain invasion" after the 1870s (Gerschenkron 1943; Kindleberger 1951; Bairoch 1989; O'Rourke 1997): between the 1870 s and the 1890 s, average tariff rates rose by 5.7 percentage points in France (to 10.1 percent) and 5.3 percentage points in Germany (to 9.1 percent). Note, however, that this anti-liberal move to higher tariffs by the leading economies on the continent is repeated in the European periphery (up 4.2 percentage points to 16.8 percent) and in our four poor Latin American countries (up 6.9 percentage points to 34 percent), regions where, one assumes, a "manufactures invasion" must have been the motivating event. We are also taught that the Latin American reluctance to go open in the late $20^{\text {th }}$ century was the product of the Great Depression and the import substitution strategies that arose from it (Diaz-Alejandro 1984; Corbo 1992; Taylor 1998). Yet, Latin America already had by far the highest tariffs in the world by the mid-late $19^{\text {th }}$ century (Coatsworth and Williamson 2002). Thus, whatever

\footnotetext{
${ }^{4}$ Only six of the thirty-five countries lowered their tariff rates between 1870 and 1890 - China, Cuba, Denmark, Mexico, the United Kingdom and the United States.
} 
explanation is offered for the Latin American commitment to high tariff walls, it must search for origins well before the Great Depression. Finally, it is not true that Asia waited for post World War II independence to switch to protectionist policies. I have already noted that there was an upward surge in tariff rates in Asia after the 1880s and early 1890s, illustrated best by Burma, India, the Philippines, Siam and Turkey. With the exception of Egypt and Japan, all of the Asian countries underwent a surge to high tariffs in the 1930s, and most of these countries stuck with these higher tariffs into the 1940s and beyond. One cannot help but wonder how much of the surge in Asian tariffs from the 1880s to the 1930s was due to a weakening colonial grip and to the expiration of "unequal treaties" signed decades earlier, both of which would have given the region the increasing autonomy to set higher tariffs according to local political economy forces.

Tariffs took two big leaps upward in the interwar decades, and these took place world wide. The first leap was in the 1920s, which might be interpreted as a return to high pre-war tariff rates. The second was in the 1930s, with the well-known and aggressive beggar-my-neighbor policies reinforced by the specific-duty-deflation effect. The biggest interwar tariff hikes in the industrial core were initiated by Germany and the UK, but France and the United States were not far behind. Indeed, the rise in tariff rates were so pronounced in the core, that the big pre-1914 spread between the high-tariff autonomous periphery and the low-tariff industrial core evaporated. Still, tariffs rose in most of the European periphery and everywhere in Latin America, except for two countries that had the highest pre-war tariffs, Colombia and Uruguay. Tariffs rose across the interwar decades in Asia and the Middle East, and the rise was especially dramatic in Burma, Ceylon, China, Egypt, India, Siam and Turkey. To give some sense of how large the rise in tariff barriers was around an Asian periphery dominated by allegedly passive and free-trading colonies, the tariff rate rose in India by 22 percentage points between 1920 and 1939 (from 5.5 to 27.5 percent), in Egypt it rose by 36.7 percentage points between 1920 and 1939, in Siam it rose by 26.9 percentage points between 1918 and 1936, and in Turkey it rose by 34.1 percentage points between 
1923 and 1937. So much for a free-trading Third World periphery before their post-1950 ISI policies.

So, what determined who protected and when they protected in the century before World War II?

\section{Was It Stolper-Samuelson or Something Else, and Why Does It Matter?}

Was the rise in tariffs and/or high tariffs before World War I driven by some anti-global reaction, that is, by some backlash? Until the race towards autarky in the 1930s, the free traders were members of the industrial core, their colonies, or those who their gunboats had intimidated to open up. The rest had erected high tariff walls. Was the autonomous periphery exhibiting global backlash? In the three decades or so following 1865 , the rise in tariff rates was ubiquitous world-wide. Was this upsurge a policy backlash response to the technological events along shipping routes and railroad lines which were serving to integrate world commodity markets and to blow the winds of international competition down the necks of import-competing industries which geography had protected before? It is essential to get answers to these questions if the modern debate about the future of globalization is to be properly informed by history. Simply to show high and/or rising tariffs is not enough. Did globalization backlash account for it?

The most elegant "backlash" explanation has its roots right here in Stockholm. Eli Heckscher and Bertil Ohlin told us how endowments could account for trade patterns, factor abundance dictating competitiveness in world markets and what would be exported by whom. Heckscher (1919: reprinted in Flam and Flanders 1991) himself showed how foreign trade effects the distribution of income, but we had to wait for Wolfgang Stolper and Paul Samuelson (1941) to elaborate the corollary (in English!), namely that the scarce factor should favor protection and the abundant factor free trade. Thus, in landscarce and labor-abundant countries, the landed elite should be pressing hard for protection. A decade or so ago, (Heckscher-)Stolper-Samuelson thinking was used with great skill by Ronald Rogowski (1989) 
who applied it to country trade policy the world around from 1840 to the present. The trouble with the Stolper-Samuelson corollary, however, is that it only tells us who votes for what, not who wins the voting. In the previous European example, when the landed elite also dominated the voting, ${ }^{5}$ the import-competing sectors got the protection from foreign grains that the landed elite wanted. Trade theorists have, in fact, offered an explicit rule (the "endowment effect") whereby the "equilibrium tariff increases with the square root of the ratio of the country's scarce factor to its abundant factor" (Magee, Brock and Young 1989: p. 25). Alternatively, as the scarce factor shrinks in relative size, its power at the polls shrinks too. However, it is not clear what happens to such "endowment" rules when the scarce factor does not have the vote, as was true of labor throughout most of the world before the 1930 s. ${ }^{6}$ Did labor get the protection of import-competing manufacturing that it should have wanted in labor-scarce Latin America, the English-speaking new world, and southeast Asia?

While the Ricardo-Viner-Cairnes specific-factor model yields results similar to the StolperSamuelson model - import-competing industries favor protection, (Heckscher-)Stolper-Samuelson thinking is probably more effective for long-run analysis like that contained in this essay (and see Magee, Brock and Young 1989: p. 12 and Chp. 7). More generally, when the import-competing sector is damaged by an adverse price shock (an improvement in the country's terms of trade) induced by world market events or by declining seaborne transport costs that reduce import and raise export prices, is there always a "compensation effect" that drives up tariffs (Magee, Brock and Young 1989: p. 22 and Chp. 13; see also Anderson and Hayami 1986: Chp. 4)? Maybe, maybe not, and it will depend largely on whether the factors in the slumping sector can escape to the booming sector. Stolper-Samuelson has a far better

\footnotetext{
5 In 1831 , only 8.6 percent of the males in the United Kingdom had the right to vote, and even in 1866 , after the First Reform Act in 1832, the figure was still only 17.8 percent. (See Lindert 1998: Table 4. ) These were, of course, the wealthy at the top of the distribution.

6 As late as 1940, the share of the population voting in Latin America was never higher than 19.7 percent (Uruguay), while the lowest figures were for Ecuador, Bolivia, Brazil and Chile (3.3, 4.1, 5.7 and 6.5 percent, respectively). Engerman, Haber and Sokoloff (2000: Table 2, p. 226).
} 
chance of explaining $19^{\text {th }}$ century tariff policy when, after all, most trade was in primary products and (immobile) specific factors played a big role. It has a far poorer chance of explaining late $20^{\text {th }}$ and early $21^{\text {st }}$ century tariff policy when trade has shifted to manufactures and most factors -- labor, skills and capital -- are mobile. ${ }^{7}$

There is no shortage of elegant "backlash" models. It's the evidence brought to bear that's scarce. While the empirical analysis of Stephen Magee, William Brock and Leslie Young is certainly impressive, their work is limited to the United States between 1900 and 1988 (1989: Chp. 13) or to a world cross section from the 1970s (1989: Chp. 16). In Rogowski's otherwise superb Commerce and Coalitions (1989), the author makes no effort to control for other tariff-setting forces that might have been at work. There are other impressive prior contributions that will motivate my own assessment of these world tariff facts between 1865 and 1938, but I will save them for the sections that follow.

\section{Was It Infant Industry or Something Else, and Why Does It Matter?}

It has always been believed that a second powerful motivation for high tariffs on imported manufactures in the pre- or early- industrial periphery is development policy. Central authorities were persuaded for much of the $20^{\text {th }}$ century that industrialization was the only vehicle for development and that protection fostered that process. Indeed, they have often cited $19^{\text {th }}$ century experience to help support these claims. I will call this motivation the infant industry argument for short, with the understanding that it includes development and industrial policy.

Does protection help or hinder growth? It should be useful to answer this question first to see

\footnotetext{
${ }^{7}$ Industrial manufactures have been a rapidly rising share of Third-World output and exports. For example, for all "developing" countries, manufactures rose from only 17.4 percent of commodity exports in 1970 to 64.3 percent by 1994. Enough of the Third World is now labor-abundant and natural-resource-scarce so that the growth of trade has helped it industrialize. The classic image of Third World specialization in primary products is obsolescing. See Lindert and Williamson (2003: footnote 22).
} 
whether policy makers in the autonomous parts of the periphery could have used such evidence to support their protectionist policies in the century before the 1930s. Of course, policy makers of that time didn't have the models, methods and evidence that I exploit in Table 1, but they certainly would have had the intuition. Were we asking this question about the late $20^{\text {th }}$ century, then the evidence would strongly support the position that protection hindered growth. But the $19^{\text {th }}$ century was different. About thirty years ago, Paul Bairoch (1972) argued that protectionist countries grew faster in the $19^{\text {th }}$ century, not slower as every economist has found for the late $20^{\text {th }}$ century. ${ }^{8}$ Bairoch's sample was mainly from the European industrial core, it looked at pre-1914 experience only, and it invoked unconditional analysis, controlling for no other factors -- it simply compared growth rates of major European countries in protectionist and free trade episodes. More recently, Kevin O'Rourke (2000) got the Bairoch finding again, this time using macro-econometric conditional analysis on a ten country sample drawn, once again, from the pre-1914 Atlantic economy. In short, these scholars have not been able to find any evidence before World War I supporting the protection-slows-growth hypothesis.

Thus, history offers a tariff-growth paradox which took the form of a regime switch somewhere between the start of World War I and the end of World War II: before the switch, protection was associated with fast growth; after the switch, protection was associated with slow growth. Michael Clemens and I (2001) have suggested an explanation for that paradox but the relevant question for this essay is whether the periphery was part of this paradox, or whether instead it was only true of the industrial core. Did protection foster ${ }^{9}$ growth in the periphery where those tariff rates were so high? Table 1 concludes that while it did in pre-World War I industrial Europe plus its rich English-speaking offshoots (the coefficient on ln own tariff $=+0.36$ and it is significant), it definitely did not in the

\footnotetext{
${ }^{8}$ Well, almost every economist. Rodríguez and Rodrik (2001) are skeptical of the open-fosters-growth conclusion about the late $20^{\text {th }}$ century.

${ }^{9}$ Caution suggests using the phrase "was associated with" rather than "fostered." I press on without caution, but subject to this understanding.
} 
periphery. In the European periphery, protection did not help growth but rather hindered it $(+0.36-0.53$ $=-0.17$ and it is significant $)$, and the same was even more true of Latin America $(+0.36-1.04=-0.68$ and it is significant).

Policy makers in those parts of the periphery which had tariff autonomy were certainly aware of the pro-protectionist infant-industry argument offered for the German Zollverein by Frederich List and for the United States customs union by Alexander Hamilton. This was certainly true of late $19^{\text {th }}$ century Latin America (Bulmer-Thomas 1994: p.140). However, it is important to stress "late" in the previous sentence since the use of protection specifically and consciously to foster industry does not occur in Mexico until the early 1890s, Brazil a little later in the 1890s, Chile in 1897 and Colombia in the early 1900s (Coatsworth and Williamson 2002). So, the qualitative evidence suggests that domestic industry protection becomes a significant motivation for Latin American tariffs only near the turn of the previous century. Table 1 is consistent with that qualitative evidence since there is absolutely no pre-World War I evidence which would have supported infant industry arguments for Latin America. We must look elsewhere for plausible explanations for the exceptionally high (and often rising) tariffs in the autonomous periphery in the century before the Great Depression. One of the alternative explanations that I will explore in the next section involves the revenue needs of central governments. As a signal of things to come, I simply note here that the causation in Table 1 probably went the other way round in Latin America. That is, countries achieving rapid GDP per capita growth would also have undergone faster growth in imports and in other parts of the tax base, thus reducing the need for high tariff rates. And countries suffering slow growth would have had to keep tariff rates high to ensure adequate revenues.

Why is it important to find no evidence supporting a protection-fosters-growth correlation in the periphery before the interwar decades? The answer, of course, is that such evidence would add more support to the view that those high and rising tariffs in the periphery represented a "globalization 
backlash" as it was "flooded with manufactures" from the industrial core. ${ }^{10}$ The periphery was flooded with ever-cheaper manufactures, as the natural barriers of geography fell in response to the railroad and steamship, and as industrial Europe and North America underwent impressive productivity advance in manufacturing. If the periphery was in fact hoping to stimulate industrial development by protection, tariffs would have had to rise higher and higher to offset the continued fall in the landed price of imported manufactures.

\section{The Political Economy of Tariffs: Some Preliminaries}

\section{Tariffs for Revenue}

Were revenues a strong motive for high tariffs? If so, were those high pre-World War I tariffs in Latin America and the European periphery really all that the market could bear? Maybe, maybe not, but as Douglas Irwin (1997: pp. 8- 12) has pointed out for the United States, the revenue-maximizing tariff hinges crucially on the price elasticity of import demand. Tariff revenue can be expressed as $\mathrm{R}=\mathrm{tpM}$, where $\mathrm{R}$ is revenue, $\underline{\mathrm{t}}$ is the average ad valorem tariff rate, $\mathrm{p}$ is the average import price and $\mathrm{M}$ is import volume. Totally differentiating with respect to $\underline{t}$, and assuming that the typical $19^{\text {th }}$ century country in the periphery was a price taker for manufacturing imports, yields $\mathrm{dR} / \mathrm{dt}=\mathrm{pM}+(\mathrm{tp}) \mathrm{dM} / \mathrm{dt}$. The revenuemaximizing tariff rate, $t^{*}$, is found by setting $\mathrm{dR} / \mathrm{dt}=0$, in which case $\mathrm{t}^{*}=-1 /(1+\eta)$, where $\eta$ is the price elasticity of demand for imports. Irwin (1997: p. 14) estimates the price elasticity to have been about -2.6 for the United States between 1869 and 1913. Since the import mix for countries around the periphery was similar to that of the United States, assuming the price elasticity for the former around -3 can't be too far off the mark. Under those assumptions, the revenue-maximizing tariff in the periphery view.

${ }^{10}$ Any evidence favoring the Stolper-Samuelson hypothesis would, of course, also support the backlash 
would have been very high indeed, about 50 percent.

Suppose some government in the periphery - riding an export boom -- had in mind some target revenue share in GDP $(\mathrm{R} / \mathrm{Y}=\mathrm{r})$ and could not rely on foreign capital inflows to balance the current account $($ so $\mathrm{pM}=\mathrm{X}$ ), then $\mathrm{r}=\mathrm{tpM} / \mathrm{Y}=\mathrm{tX} / \mathrm{Y}$. Clearly, if foreign exchange earnings from exports (and thus imports) were booming (an event which could be caused by a terms of trade boom, denoted here by a fall in the relative price of imports, $\underline{p}$, or by a supply-side expansion which increased export quantities, $\mathrm{X})$, then the target revenue share could have been achieved at lower tariff rates, $\underline{\mathrm{t}}$. The bigger the export boom, the higher the export share, the bigger the import share, and the lower the necessary tariff rate.

So, did independent governments in Latin America, the European periphery and Asia act as if they were meeting revenue targets? Ceteris paribus, did they lower tariff rates during world primary product booms when export shares were high and rising, and did they raise them during world primary product slumps?

Of course, countries in the periphery which were successful in getting external finance from the European core would have had less reason to use high tariffs to augment revenues in the short run and medium term. Since world capital markets became increasingly well integrated up to 1913 (Obstfeld and Taylor 2003), high tariffs that were necessary in 1865 would no longer have been necessary in 1913 if "revenue smoothing" was a key motivation. However, there may have been plenty of motivation to raise them again when world capital markets fell apart in the interwar years. Furthermore, countries that developed internal (and less distortionary) tax sources would have had less need for high tariffs, an event that started in the late $19^{\text {th }}$ century industrial core, accelerating during the interwar rise of the welfare state (Lindert 1994). Such developments lagged behind in the periphery, however.

\section{Productivity Advance Abroad and De-Industrialization Fears at Home}

Were high and rising tariffs in the periphery generated by de-industrialization fears? Three things 
are essential to the survival of domestic industry: low costs of inputs -- like labor, power and raw materials; high productivity in the use of those inputs; and high market prices of output. Policy makers in the periphery could not do much about the first two, ${ }^{11}$ but they could do a great deal about the third by pushing up tariff barriers, excluding foreign imports and thus raising the domestic price of manufactures relative to other products produced for home or foreign markets. When industrial productivity advance in the core was fast, world market prices of manufactures would decline relative to other products, and foreign firms would be increasingly competitive in local periphery markets. Thus, policy makers in the periphery who favored industry would have had reason to raise tariffs in response to any sharp decline in the relative price of manufactures, especially relative to prices of the primary products the periphery exported to Europe. In short, if the periphery had de-industrialization fears, it would have raised tariffs in response to falling prices of manufactures in world markets.

Note that a decline in the world price of manufactures is equivalent to a rise in the world price of primary products, and thus to an improvement in the periphery's terms of trade. But to the extent that a rise in the terms of trade facing some primary-product specializing country created an export boom there, we have already controlled for this influence on tariffs through the revenue effect -- booming X/GDP implies booming tariff revenues and less need for high tariff rates. Now we have another potential and offsetting effect driven by de-industrialization fears: an improvement in the periphery's terms of trade implies a decline in the relative price of manufacturing imports, a de-industrialization threat (also called the Dutch disease), and thus a protectionist reaction. Which of these forces dominated tariff-setting behavior?

\footnotetext{
${ }^{11}$ Except, of course, that they could keep the price of imported raw material intermediates low by giving such imports tariff concessions.
} 


\section{Evaporating Geographic Barriers and the Tariff-Transport Cost Trade Off}

Whatever the motives for tariffs, high transport costs on goods imported from one's trading partner are just as protective as high tariffs. When new transport technologies induce a dramatic fall in freight costs, the winds of competition thus created give powerful incentives to import competing industries to lobby for more protection. Since there certainly was a transport revolution across the $19^{\text {th }}$ century (O'Rourke and Williamson 1999: Chp. 3), there was plenty of incentive for manufacturing interests in the periphery and agricultural interests in the core to lobby for protection as the natural barriers afforded by transport costs melted away. This connection was confirmed long ago for the "invasion of grains" into Europe from the United States, the rest of the new world, and Russia. But what about the "invasion of manufactures" into the periphery from industrial Europe?

The transport revolution took many forms, but three mattered most: a decline in overseas tramp freight rates; the appearance of major canals, like the Suez and the Panama; and the penetration of railroads into interior markets. Tramp freight rates fell everywhere, but mainly on routes carrying high bulk intermediates and foodstuffs to Europe, much less on routes carrying low bulk manufactures to the periphery. Meanwhile, railroads penetrated everywhere, and this fact might have been especially relevant for tariff policy where markets were mainly located in the interior. If railroads exposed previouslyisolated interior local manufacturing to increased foreign competition, those interests should have lobbied for more protection, and railroad penetration of the interior was especially important in Latin America, eastern Europe and even India.

\section{Strategic Trade Policy, the Terms of Trade and Tariffs}

A well-developed theoretical literature on strategic trade policy ${ }^{12}$ predicts that nations have an incentive to inflate their own terms of trade by raising tariffs, unless, of course, trading partners agree to

\footnotetext{
${ }^{12}$ Exemplified by Dixit (1987) and recently surveyed in Bagwell and Staiger (2002).
} 
mutual concessions. According to this kind of thinking, a country's own tariffs will depend at least in part upon the country's external tariff environment. Elsewhere, a principal-trading-partners'-tariff index has been calculated for our 35 countries (Blattman, Clemens and Williamson 2002): first, the major trading partners for each country are identified; second, exports going to each major trading partner as a share of total country exports going to all major trading partners is calculated; third, these shares are then used as weights by which the average tariff faced by each country is constructed. This principal-tradingpartners'-tariff index is revealing. In the two decades before World War I, every region except the industrial core and Latin America faced much lower tariff rates in their main export markets than they themselves erected against competitors in their own markets. The explanation, of course, is that the main export markets were located in the European core, where tariffs were much lower. Thus, most of the periphery faced much lower tariffs than did the core, although this was not true of Latin America for whom the protectionist United States was such an important market. During the interwar there was convergence: every regional club faced very similar and high tariff rates in export markets, but those rates facing the periphery were rising very steeply as the core made that big policy switch from free trade to protection.

It might pay to repeat that Latin America, for example, faced far higher tariffs than anyone else since they traded with the heavily-protected United States. What the United States was doing with tariff policy must have mattered a great deal to Latin America. So, did this "hostile" policy environment abroad trigger a like response at home? While the strategic trade thesis holds promise in helping account for higher tariffs in Latin America and in that part of the European periphery trading with moreprotectionist France and Germany, it holds less promise for that part of the European periphery whose exports were sent to free-trading United Kingdom. Indeed, between 1900 and World War I a decline in partner tariffs took place everywhere in the periphery except in the European periphery, suggesting an interesting leader-follower reaction that varied across the periphery depending on who the dominant 
trading partner was, e.g. an ultra-protectionist United States lowering tariffs, a moderately protectionist France and Germany raising tariffs, or a free trade Britain standing pat (see Blattman, Clemens and Williamson 2002).

\section{The (Heckscher-)Stolper-Samuelson Theorem}

Ronald Rogowski (1989) has used the Stolper-Samuelson theorem to suggest that we look to lobbying capitalists to find a political economy explanation for those extraordinarily high Latin American tariffs. Although their economies certainly varied in labor-scarcity, every Latin American country faced relative capital scarcity and relative land abundance. As the Stolper-Samuelson theorem has it, protection benefits (and trade liberalization harms) owners of factors in which that society is poorly endowed. According to this kind of thinking, Latin American capitalists should have been looking to form protectionist coalitions as soon as the belle époque began to threaten them with freer trade. In most cases, they did not have to look far, either because they managed to dominate oligarchic regimes that excluded other interests, or because they readily found coalition partners willing to help, or both (Coatsworth and Williamson 2002).

Why no scarce labor in the Latin American tale? Growth, peace and political stability after 1870 did not necessarily produce democratic inclusion in Latin America. Most countries in the region limited the franchise to a small minority of adult men until well into the $20^{\text {th }}$ century. Literacy and wealth requirements, in addition to lack of secrecy in balloting, excluded, as we have seen, most potential voters in virtually every country (Engerman, Haber and Sokoloff 2000). Thus, the late $19^{\text {th }}$ century tended to produce oligarchic governments in which urban capitalists -- linked to external trade and finance -played a dominant role. In countries that specialized in exporting agricultural products, free-trading landowners formed the second dominant part of the governing oligarchy. Free-trading mineral export interests usually had less direct leverage in governmental decision making, despite the size and 
significance of their investments. Thus, unambiguous protectionist outcomes would hardly have been predicted for every Latin American country.

To the extent that Stolper-Samuelson thinking is useful in accounting for the variance in tariff rates the world around before World War II, we would except plenty of regional differences, as Rogowski has argued. After all, very different endowments and political participation characterized various parts of the periphery. The land-abundant English-speaking new world were places where scarce labor had a powerful political voice to lobby for protection, joining scarce capital. The European periphery had scarce land and capital lobbying for protection, while the voices of free-trading labor were suppressed. Southeast Asia had scarce labor and capital, but with political participation limited to freetrading landed interests. The rest of Asia was pretty much land and capital scarce, but free-trading labor had little or no political voice. The important point here is that the Stolper-Samuelson theorem tells us who should vote for free trade and who for protection, but it does not tell us who gets the most votes.

\section{Price Instability and the Specific-Duty Effect}

Inflations and deflations have had a powerful influence on average tariff rates. Recall that import duties were typically specific until modern times, quoted as pesos per bale, yen per yard, or dollars per bag. Under specific duty regimes, abrupt changes in price levels change import values in the denominator, but not the legislated duty in the numerator, thus producing big equivalent ad valorem or percentage rate changes. This specific-duty effect implies, of course, that debating the tariff structure is politically expensive, and thus is only infrequently changed by new legislation. The specific-duty effect has been explored most fully for the United States (Crucini 1994; Irwin 1998: p. 1017), but also for Mexico (Marquez 2002: p. 307), and, more generally, for Latin America (Coatsworth and Williamson 2002). The specific-duty effect has not, however, been explored at a global level. Nor does the literature tell us why specific duties seem to be much more common in young and non-industrial countries, 
especially if they are poor. One answer might be this: Honest and literate customs inspectors are scarce in poor countries, but they are essential for implementing an ad valorem tariff where import valuation is so crucial. So, legislators impose specific duties to minimize the "theft" of state tariff revenues by dishonest and illiterate customs agents. This explanation suggests that the specific-duty effect should diminish over time as literate and honest customs inspectors became more abundant, especially in the periphery. Another answer might be this: Poor countries export primary products, and they tend to concentrate on only a few. On both counts, poor countries expose themselves to price instability. Since export revenues and import expenditures are highly correlated, unstable export prices imply unstable export values and, finally, unstable tariff revenues. A specific duty tends to stabilize the impact of the export price instability on government finances.

\section{Policy Packages and Real Exchange Rate Trade-Offs}

Few policies are decided in isolation from others. Indeed, there were other ways that governments could have improved the competitive position of import-competing industries, if such protection was their goal, and they explored many of these alternatives in the 1930s and in the ISI years that followed. Yet, they clearly understood these alternatives even before World War I. One powerful alternative involved manipulating the real exchange rate. If governments chose to go on the gold standard or to peg to a core currency, they got more stable real exchange rates in return (and an attractive advertisement for foreign capital). However, since protection via real exchange rate manipulation was forgone, tariff rates would have to go up to reclaim that protection lost. Did countries exploit this tradeoff both during the years of gold standard commitment before World War I and during the interwar years when everybody went off gold? 


\section{The Political Economy of Tariff-Rate Setting: Empirical Analysis}

The potential explanations for tariff policies discussed in the previous section can be allocated to four main categories or motives: strategic trade policy, revenue needs, infant industry development goals, and global backlash (a tariff compensation). The impact of price instability under regimes of specific duties I take to be extraneous, and the treatment of tariffs as a policy trade-off within some full fiscal system, while given some attention here, I take to be challenge enough to require a separate paper. I also use colonial status as a control for tariff autonomy. These four central motives need not have been competing. Still, even though each may have played a role before World War II, we would like to know which played the biggest roles, and in which periods and places. Elsewhere, an econometric attack has been launched on the problem two ways (Blattman, Clemens and Williamson 2002; Clemens and Williamson 2002; Coatsworth and Williamson 2002): first, by treating the experience as comparative world economic history and thus exploring time series only (TS); and second, by exploring the crosssection variance across these 35 countries using time fixed effects (CS). The cross-section results are transformed to remove serial correlation (using the AR(1) Cochrane-Orcutt correction), and the time series are estimated using random effects (RE) after likewise correcting for serial correlation (with a Baltagi-Wu estimator). What I report here summarizes the main findings.

Table 2 presents the time series and cross section results. Each of these contains five columns, necessitated by the fact that data coverage for inflation and the terms of trade is inferior to that of the other regressors. The right-hand side variables suggested by the previous section are the following (all but dummies in logs):

Lagged Export Share. This export/GDP ratio is a measure of export boom, where we expect booms in 
the previous year to diminish the need for high tariff rates this year -- if government revenues are a key motivation -- thus yielding negative coefficients in the regression; ${ }^{13}$

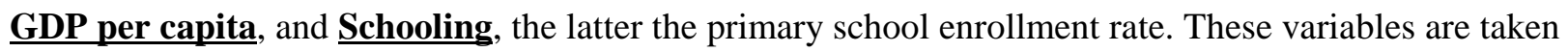
as proxies for skill endowments, with the expectation that the more abundant the skills, the more competitive the industrial sector, and the less the need for protection, thus yielding a negative coefficient in the regression;

Population. Large countries have bigger domestic markets in which it is easier for local firms to find a spatial niche. Alternatively, bigger populations imply higher density, a fact which makes domestic tax collection easier and tariff revenues less necessary. In either case, the demand for protection should be lower in large countries, and the regression should produce a negative coefficient;

Lagged Partner Tariffs. Strategic tariff policy suggests that countries should have imposed higher tariffs this year if they faced higher tariffs in their main markets abroad last year;

Effective Distance. The distance from each country to either the United States or the United Kingdom (depending on trade volume), adjusted by seaborne freight rates specific to that route. If protection was the goal, effective distance should have served as a substitute for tariffs, so the regression should yield a negative coefficient;

$\underline{\text { Railway Mileage added in kilometers. Poor overland transport connections to interior markets serves as }}$ a protective device. Railroads reduce that protection, requiring higher tariffs to offset the effect. Thus, the regression should yield a positive coefficient;

\footnotetext{
${ }^{13}$ In related paper on Latin America (Coatsworth and Williamson 2002), capital inflows from Britain were added to the analysis for the years 1870-1913. This variable measured annual British capital exports to potential borrowing countries. Countries favored by British lending were shown to have had less need for tariff revenues and thus had lower tariffs. The variable does not appear here since our source does not report the period 1914-1938. Similarly, I do not report the gold standard effect here, although we now have the data to report the answer: being on the gold standard was associated with higher tariff rates, as predicted.
} 
Inflation and inflation-squared. To the extent that countries used specific duties, inflation should have lowered tariff rates, thus yielding a negative coefficient. However, very rapid inflation might well have triggered a speedier legislative reaction with increases in specific duties, thus yielding a positive and offsetting coefficient on the squared term in the regression;

$\underline{\text { Federal }}$, a dummy variable; if a federal system $=1$, if centralized $=0$. Federal governments had a stronger need for customs duties (since joining members retained their tax authority), while centralized governments could better exploit internal revenue sources. Thus, the regression should report a positive coefficient;

Colony, a dummy variable; if a "colony" $=1,0$ otherwise. Those which were colonies over the full period 1870-1938 are: Burma, Ceylon, India, Indonesia, the Philippines. Other colonies changed their status during our period. The following were colonies, or acted like colonies, during some part of our period: Cuba (1870-1901), Egypt (1882-1938) and Serbia (1870-1920).

Urbanization, taken as share of population in cities and towns greater than 20,000. This urbanization statistic is taken to be a Stolper-Samuelson proxy for the lobbying power of urban capitalists and artisans in the periphery, thus yielding a positive coefficient in the periphery regressions;

Terms of Trade Index. In the periphery, this terms of trade variable measures the price of each jth country's primary product exports (Pxj) relative to the price of manufactures $(\mathrm{Pm})$ in world markets. In the core, the opposite is the case. If de-industrialization fears in the periphery were dominant, a positive coefficient should appear: price shocks in world markets that were good for the periphery's export sectors were bad for import competing sectors inviting compensation for the injured parties. Thus, the sign on $\ln ($ Lagged $\mathrm{Px} / \mathrm{Pm})$ should tell us whether de-industrialization fears dominated in the periphery. In the European core and in land scarce Asia (like Japan), their imports were dominated by foodstuffs and raw materials. Here, Px/Pm speaks to "invasion of grains" fears, whether wheat or rice, inviting compensation for the injured parties in this case too (even today: see Anderson and Hayami 1986). 


\section{Comparative Tariff History Results}

Turning first to the time series, we see that all coefficients have the expected sign with the exception of schooling (at least some of the time). Revenue motivation is revealed since export booms were associated with lower tariffs. Backlash and compensation forces are revealed too, and in many ways. Decreases in overseas transportation costs were associated with an offsetting rise in tariff barriers, and increases in the length of the domestic rail network were associated with a symmetric rise in tariffs. As geographic barriers evaporated, import-competing industries were compensated by higher tariffs. Also, an improvement in a country's terms of trade in world markets generated a strong anti-global reaction. For the periphery, this took the form a de-industrialization reaction since an improvement in the relative price of their primary product export in world markets implied a fall in the relative price of imported manufactures, inviting a tariff-raising lobbying reaction by industrial interests at home. For the European core, this took the form of a grain invasion reaction, as a rise in the relative price of their manufacturing exports implied a fall in the relative price of their imported foodstuffs, inviting a tariffraising lobbying reaction by landed interests at home. There is strong support for strategic tariff motives, since partner tariffs has a positive and significant coefficient throughout. The results for both schooling and urbanization depend on whether we control for inflation or not. Since including inflation reduces the sample size by almost half, however, we do not know if the different results for schooling and urbanization are due to the restricted sample or to the fact of controlling for inflation. In the full sample, an increase in urbanization was associated with an increase in tariffs, just as the Stolper-Samuelson theorem would predict, at least in the capital-scarce periphery. Tariff rates fell with increases in GDP per capita, a result consistent with modern surveys of global attitudes (O'Rourke and Sinnott 2003) but which I also find consistent with the Stolper-Samuelson theorem. Internal market size mattered in the predicted way: large countries had lower tariff rates. Finally, note that inflation did not have a consistent 
effect throughout the period, even though Figure 1 suggests that it did during wartime episodes. I believe this is due to the limited sample with inflation coverage underlying Table $2 .{ }^{14}$

Judging by the estimated elasticities, increases in trading partner tariffs were by far the most powerful determinant of increases in own tariffs over the full seven decades, at least on the economic margin. Changes in GDP per capita, population, and schooling had elasticities next in size. The combined influence of geography -- the sum of falling effective sealane distance and rising railway mileage -- also had high elasticities, but they still were only half that of partner tariffs. The same is true of the terms of trade index. Much to my surprise, the lowest elasticity reported in Table 2 is that attached to changes in the export share, suggesting that revenue motives were not a dominant force after 1865 . In section 7 , however, we shall see that it was the dominant force before that date.

Having analyzed both statistical significance and marginal economic importance, what about historical significance? To see the difference, consider this example: Suppose that own tariffs were highly responsive to partner tariffs in the European periphery. Suppose also we observe that own tariffs rose in the European periphery. Was this anti-global tariff rise due to changes in partner tariffs or some other force? We cannot answer this question without knowing how much partner tariffs changed. To pursue this example further, if partner tariffs barely changed, then we would have to look elsewhere for explanations of the historical rise in own tariffs despite the fact that for a given change in partner tariffs we see a large change in own tariffs. This case illustrates the difference between big marginal economic impact and big historical significance.

Why were tariffs on the rise nearly everywhere in the decades before 1900? Elsewhere, it has been shown that growing GDP per capita and population size were serving to lower tariffs everywhere, but these were overwhelmed by tariff-raising forces (Blattman, Clemens and Williamson 2002). The push

\footnotetext{
${ }^{14}$ Ongoing work is repairing this data limitation, and the specific-duty effect is confirmed in the larger sample. In addition, recall that the analysis in Table 2 excludes World War I, and we know these years to have been ones during which the specific-duty effect was powerful.
} 
for higher tariffs came mostly from two sources: first, domestic political economy forces associated with urbanization and schooling; and second, a protectionist reaction as a compensation to import-competing industries as openness was thrust upon them by advances in transportation technology (both on land and sea). Only in the European periphery do we observe partner tariffs making a major contribution to the anti-global, tariff-raising dynamics during this period. Falling transportation costs certainly did contribute to rising tariff barriers in the European core, in the non-Latin European offshoots and in Asia. Yet, transport revolutions along the sea lanes had little impact on tariffs in Latin America and the European periphery, simply because the fall in overseas freight rates were more modest there. In addition, there is strong evidence of de-industrialization fears in the periphery, joining de-agricultural fears in the core. Overall, it appears to have been rising levels of railway penetration, schooling, urbanization (associated with changes in domestic politics) and improving terms of trade (at least up to the 1890s) that drove tariffs upwards world wide.

For the period from the 1890s to World War I, those anti-global domestic political economy and (dissipating) transportation forces pushing tariffs upwards were finally overwhelmed by surging proglobal forces: falling tariffs are associated with rising per capita incomes in Europe, their non-Latin offshoots and Latin America, carried in large part by mass migrations and capital exports. Once again, the terms of trade effect was operative, but now in a pro-global way. As the long run deterioration in the relative price of primary products (made famous by Raoul Prebisch) started after the 1890s, the relative rise in the price of imported foreign manufactures eased the competitive pressure on local industry in the periphery. During the interwar decades, the massive increases in tariffs were driven almost entirely by increases in partner tariffs, a force that seems to eclipse everything else. 


\section{Cross Section Results}

Now consider the cross-section results in Table 2. Here we control for two additional characteristics: colonial status_an indicator of autonomy over tariff policy; and federal status—an indicator of the decentralization of governance.

Three variables appear to change sign between time series and cross section. The partner tariffs variable is not significant in cross section and appears to be negative. How can this be consistent with a world in which, as we have seen, changes in a country's own tariff is closely associated with changes in its trading partners' tariffs? This cross sectional pattern suggests that initial conditions were such that, before reacting to changes in their partners' tariffs, countries began from a distribution in which high own tariffs just happened for other reasons to be associated with low partner tariffs and vice versa. This pattern would appear to fit Asia's initial conditions at the dawn of the $20^{\text {th }}$ century: their own tariffs were forced to be low, either as colonies or as victims of gunboat diplomacy, while high tariffs prevailed in their American and European trading partners. The European periphery would appear to fit this characterization too: their backlash before World War 1 left them with high tariffs at a time when their trading partners in the European core had recently moved toward freer trade. The numbers bear this story out: in 1925, average own tariffs and average trading partner tariffs were respectively $6.7 \%$ and $10.0 \%$ for Ceylon, China, Indonesia, Japan, and the Philippines. In the same year, those two numbers were $12.7 \%$ and $6.6 \%$ for Greece, Norway, Portugal, Russia, Serbia, Spain, and Sweden. After 1925 all these countries reacted to tariff hikes in their trading partners by raising their own tariffs, so both numbers in these pairs went up. This shows up in time series as a positive coefficient on trading partner tariffs, but the initial distribution of tariffs shows up in cross section as a negative coefficient. Similar initial conditions can explain the negative cross-sectional coefficient on urbanization: agrarian and rural Russia with its high tariffs at one extreme, and industrializing and urban Japan with its low tariffs at the other. 
What about historical significance? Why were tariffs so low before 1914 across Asia, the Middle East, and the European core? One reason was the large internal markets in these labor rich and land scarce economies. Another was the industrial competitiveness of the European core as captured by GDP per capita. Why were tariffs so high in both Latin and non-Latin European offshots? It appears that smaller domestic markets in the Latin and non-Latin European offshoots made it harder for firms to survive in a niche without walls to protect them, and, of course, they were less competitive. While the revenue motive is present, and while the signs and magnitudes on the export share coefficient are the same in cross section and time series, the influence is less powerful in the cross section, a result I find surprising especially given the findings in the section that follows.

\section{Looking Earlier: the United States Customs Union 1789-1820, the}

\section{Emerging German Zollverein 1818-1834, and the Latin America Non-Customs Union 1823-1867}

While tariff and tariff-determinants data may not be as comprehensive before the 1860 s, the tariff policy of three important young republics (or clusters of young republics) confirms the central conclusions coming from our econometric analysis of the larger post-1865 world sample of which they are a part. Two motivations seem to explain high (and often rising) tariffs in the early federal republic of the United States, the early German Zollverein, and the early republics of Latin America (which failed to form a new customs union after having lost the old one under Iberian colonial control). The first motivation was the central government's revenue needs. The second motivation was strategic tariff policy, reciprocity and the terms of trade. Infant industry and Stolper-Samuelson were not important forces motivating tariff policy in the early years of these young republics. 


\section{The United States Customs Union 1789-1820}

As Fiona McGillivray (2001: pp. 80-1) has recently noted with persuasive elegance, the young United States of America was just a loose confederation of thirteen states in 1783. The newlyindependent United States was an important market for Britain, it and the rest of British America accounting for much more than half of its exports, ${ }^{15}$ and Britain exploited this asymmetry between its own customs union and the United States confederation for all it was worth. After all, British merchants could land "their goods in the ports of those states offering the most favourable terms" and those goods could then be re-exported across state borders tariff-free (McGillivray 2001: p. 81). Inevitably, each state competed for British business by lowering tariff rates, creating a classic "race to the bottom" with shrinking government revenues (and thus expenditures on social overhead) and, one supposes, a deteriorating terms of trade. When the United States voted for the Constitution in 1789, it turned over authority for interstate and foreign trade to a federal authority, congress. Political debate "anticipated that this rule change would alter the asymmetric nature of [the] trading relationship between the United States and Britain" and that a common external tariff would "force open British markets" (McGillivray 2001: p. 80; see also Taussig 1892). Strategic tariff policy was a central motivation behind the 1789 Constitution and the high (and rising) tariffs that emerged shortly thereafter. Those higher tariffs and the unified customs union made it possible for the United States to extract better terms of trade from the British after 1789, exploiting reciprocity.

Figure 3 plots the result, based on a recent paper by Douglass Irwin (2002). Tariff rates rose from something probably in the single digits before 1789, to about 17 percent across the 1790 s, 21 percent in the 1800 s, 26 percent in the 1810 s and almost 30 percent in $1820-21 .{ }^{16}$ As it slowly made its famous

\footnotetext{
${ }^{15}$ In 1797-98, 57.4 percent of English exports went to the Americas (O’Brien and Engerman 1991: Table 4, p. 186).

16 These tariff rates are calculated as customs revenues minus drawbacks (if re-exported) divided by imports values minus re-exports.
} 
conversion to free trade, Britain's tariff rates had fallen to the 30 percent level by the late 1830 s, about the same as the United States. But the European core and the North American periphery were moving in opposite directions: average tariff rates in Britain fell from 53 to 15 percent from the early 1820 s to the late 1850s, while French tariff rates fell from 20 to 10 percent over the same three decades (Nye 1991: Table 1, p. 26); in contrast, average tariff rates in the United States continued their rise to about 40 percent in the late 1820 s, after which angry southern free trade interests negotiated a compromise with northern protectionist interests.

Apart from using strategic tariffs to extract a better terms of trade from Britain, what else accounts for these high and rising tariff rates in the United States? Was it the infant industry arguments made in Alexander Hamilton's famous Report on Manufacturing which he delivered to the House in December 1791? Apparently not, as Irwin documents so persuasively: "Hamilton preferred modest duties because, in his view, the tariff was more important as a tool of fiscal policy than as an instrument for promoting manufactures" (Irwin 2002: p. 16). Was it Stolper-Samuelson? It would have been surprising if it were, given that the domestic industry was so tiny in the early republic and its potential lobbyists were so few. It was revenues that motivated United States tariffs in the early republic, even in a period which produced Hamilton's Report on Manufactures, a document quoted out of context by every protectionist since!

\section{The Emerging German Zollverein 1818-1834}

It appears that Rolfe Dumke (1994) has recently overturned 150 years of conventional wisdom about the political economy of the Zollverein. The conventional wisdom was helped along by Friedrick List, a contemporary economic publicist who wrote his famous The National System of Political Economy in 1841, just seven years after the Zollverein was established and shortly before its first renewal in 1842. List argued that "the Zollverein was a necessary step to protect the nascent German industry 
from the overwhelming threat of cheap English manufactured goods," so that the "protection of infant industries, not free trade, would be the appropriate policy" (Dumke 1994: pp. 10-11). Later in the century, List's undocumented assertions became established (but still undocumented) wisdom in the hands of the German Historical School and its leader Gustav von Schmoller (1904) who argued "that the main reason for the creation of the Zollverein ... was the need to protect Germany from English competition" (Dumke 1994: p. 11).

All of us have cited List and Schmoller when appealing to the infant industry argument, but was the threat of de-industrialization the real motivation lying behind the Prussian tariff of $1818^{17}$ and the German customs union that emerged around that Prussian core in 1834? Dumke shows quite persuasively that it was not. What mattered most were net government revenues, and economies of scale in tariff administration was at the heart of the story. Table 3 documents the scale economies in fiscal administration for the Zollverein and some of its members in the two decades 1818-1834. The Zollverein -- a big customs union covering 9569 German meilen -- paid 14.7 cents on every dollar collected, while Bavaria -- one-seventh the size of the Zollverein -- paid 25 cents on every dollar collected. The cost went up as member size went down: Württemburg -- one-twenty-seventh the size of the Zollverein -- paid 43 cents on the dollar, and the tiny members Kurhessen and Hessen-Darmstadt could not even collect positive net revenues given the high administrative costs. Were these two tiny members unusually small? No. Of the 34 member states Dumke lists (1994: Table VI, p. 55), 24 fell below the small (and uneconomic) size of Kurhessen and Hessen-Darmstadt. Figure 4 uses the Kuehne Ratio to estimate those scale economies more precisely for 34 Zollverein members. Ludwig Kuehne was a Prussian civil servant who wrote an essay in 1836 showing how net revenues are proportional to the area of the country imposing the tariffs (and dealing with smugglers): indeed, the ratio of border length to area (the Kuehne

\footnotetext{
${ }^{17}$ Until 1818, Prussia had no customs frontier in the modern sense. Customs and excise duties were collected at town gates and markets. "The tariff of 1818 abolished some sixty internal customs barriers [and] unified all the Prussian provinces as far as customs was concerned.” Henderson (1962), pp. 93-4.
} 
ratio) correlates very well with the actual ratio of administrative costs to gross customs revenues. When a Kernel regression is estimated for Figure 4 it implies that countries had to be larger than 2500 square miles in area to bring in positive net revenues from tariffs, and had to be larger than 7500 square miles before net revenues were significant. Members of the Zollverein of that size had 1830 populations of: Baden 1,200,471; Sachsen 1,402,066; Württemburg 1,575,051; and Hannover 1,646,745 (Kraus 1980).

With this evidence on scale economies in customs administration in hand, the political economy of the Zollverein takes on a very different shape than that made famous by List and Schmoller. It appears that the Zollverein was not a response to an invasion of British manufactures, but rather was motivated by the net revenues it generated. While that high tariff wall may well have offered significant protection to German industry and fostered specialization and trade creation within the Zollverein boundaries, it was not the most important motive for forming the customs union. It was revenues, and, one suspects, terms of trade gains with Britain coming from strategic tariff behavior.

\section{The Latin American "Non-Customs Union" 1823-1867 ${ }^{18}$}

Economic historians refer to Latin America's first half century of independence from colonial Spain and Portugal as "the lost decades." In spite of an immense improvement in the region's terms of trade from 100 to 162 over the four decades following 1820 (Bértola and Williamson 2003: Figure 2), the region's GDP per capita did not grow at all (-0.07 percent per annum up to 1850, when Europe grew at 0.97 percent per annum). By the end of the period, it also had the highest tariff rates in the world. Why the lost decades and why the high tariffs? What was exceptional about these Latin American republics?

While the rest of the world flourished under pax Britannia conditions, Latin America was violent and politically unstable. One scholar reports 10 major Latin American wars between 1825 and 1879 when conflicts are limited to those that produced at least 1,000 battlefield deaths (Mares 2001). Another

\footnotetext{
${ }^{18}$ This section relies heavily on Coatsworth and Williamson (2002) and Bértola and Williamson (2003).
} 
counts 33 major international and civil wars between 1819 and 1880 (Centenos 1997). Argentina, Brazil, Chile, Cuba, Mexico, Peru and Uruguay all fought at least two major wars between independence and 1880. Only Brazil and Chile (after 1830) avoided violent military coups. Thus, practically all of Latin America experienced extended and repeated episodes of massive and prolonged civil strife.

This universal preoccupation with national defense and internal power struggles pushed the newly independent Latin American countries toward higher revenue-maximizing tariffs. Military expenditures quickly rose to consume over 70 and often more than 90 percent of all revenues (Centenos 1997). Weak governments, under attack from within and without, abandoned internal taxes that required an extensive and loyal bureaucracy, and concentrated instead on tax collection at a few ports and mines. The ratio of tariff revenues to import values rose in every country for which there are data as did the customs revenues as a percentage of national government revenues.

Between 1821 and 1867, Mexico suffered foreign invasions by Spain, the United States, and France, the secession of Texas, 13 major regional revolts, and at least 60 peasant rebellions and indigenous caste wars (Coatsworth 1988). Mexico's first tariff law in 1821 imposed a 25 percent ad valorem tariff on all imports. The tariff rate rose still further thereafter: it averaged 36 percent for the $1820 \mathrm{~s}$ as a whole, then rose to 45 percent in the 1840 s and peaked at 46 percent in the 1870 s and $1880 \mathrm{~s}$ (Beatty 2001: p. 53). In Brazil the ratio of import duties to imports rose from 15 percent to nearly 30 percent by the 1860s (Leff 1982), a rise that was fueled by costly wars with Uruguay, Argentina, and Paraguay as well as by frequent regional and separatist revolts, slave insurrections, and a massive social and racial upheaval in the Amazon region (Leff 1982; Cleary 1998). Argentine tariff policies followed the examples of Brazil and Mexico. The independence wars (in which Argentine armies invaded Bolivia and Chile), international conflicts and blockades that followed, all served to push tariff rates upwards. Until 1865, the province and city of Buenos Aires functioned as an independent state, frequently at war 
with one or more of the interior provinces. Military expenditures forced Argentine governments to use high tariffs as a revenue device.

In every young, recently independent economy with low capacity to tax, few bureaucratic resources to implement efficient collection, and limited access to foreign capital markets, customs revenues are an easy-to-collect source of revenue essential to support central government expenditures on infrastructure and defense. This was also true for the Latin American republics beset in the first half of the $19^{\text {th }}$ century with the collapse of the colonial fiscal system. But what makes Latin America unusual was the frequency and intensity of civil wars, foreign invasions and violent border disputes. Perhaps related to the violence and instability, Latin America also did not have access to European capital markets until later in the century, ${ }^{19}$ an event that would have eased the need for tax revenues in the short run. Thus, the average share of customs duties in total revenues across the Latin American republics was 58 percent between 1820 and 1890 (Centenos 1997: Table 1). Customs revenues were even more important for federal governments (66 percent), since local and state governments who form a union typically are reluctant to give up their limited tax weapons.

To summarize, international and internal warfare both played a major role in pushing the newly independent Latin American republics toward exceptionally high tariffs designed to maximize fiscal revenues. Between 1820 and 1870, most Latin American governments erected enormous tariff barriers that may have served to protect import competing industries, but their political motivation was not protection but rather to keep troops in the field against foreign and domestic enemies. The fiscal imperative of the region's endemic military conflicts swamped all other preoccupations.

High tariffs weren't the only way that independence induced de-globalization in the young Latin American republics, helping account for those lost decades. Another important force was the collapse of the de facto customs union under previous colonial rule (Bulmer-Thomas 1994: pp. 28-31; Prados 2003:

\footnotetext{
${ }^{19}$ Indeed, there was capital flight from the young republics.
} 
p. 2). To the extent that the colonial umbrella fostered trade and factor mobility within the region, then all of those gains were lost after independence created so many small republics, a veritable balkanization of Latin America.

Balkanization plays an important role in the literature on $19^{\text {th }}$ century Latin America, as well it should. In 1850, the four biggest Latin American countries (Brazil, Columbia, Mexico, Peru) had on average populations one-sixth the size of the four biggest west European countries (France, Germany, Italy, United Kingdom). The next five mid-sized Latin American countries (Argentina, Bolivia, Chile, Cuba, Venezuela) had on average less than one-third the size of the average mid-sized western European country (Belgium, Netherlands, Portugal, Sweden, Switzerland). Small populations made for small markets, but low per capita income made them even smaller. Maddison's (1995) per capita income estimates put the per capita incomes of these five mid-size Latins at 45 percent of the five mid-sized Europeans, implying that Latin American domestic markets were less than 15 percent of the size of such modest-sized European countries. One can also relate this balkanization of Latin America to the fiscal scale economies noted in the previous section on the Zollverein. Baden, a joining member of the Zollverein, was too small while independent to be able to collect tariff revenues that exceeded administrative costs. In 1850, thirteen of the twenty Latin American republics fell (well) below Baden's 1830 population size: Argentina, Costa Rica, Cuba, Dominican Republic, Ecuador, El Salvador, Guatemala, Haiti, Honduras, Nicaragua, Paraguay, Puerto Rico and Uruguay (Bulmer-Thomas 1994: Table 2.4, p. 38).

We simply do not know how large the scale economy loss was to Latin America, just like we do not know how large the economies were to a United States which, after it successfully threw off the British colonial yoke, kept the customs union which came with the previous colonial status. But it seems likely that the Latin American configuration of small national states imposed an enormous burden in terms of lost scale economies, including fiscal scale economies. Those exceptionally high Latin 
American tariff rates may also reflect the fact that those small republics had to try to offset high administrative costs.

\section{Where Do We Go from Here?}

While surveying the political economy of trade policy, Dani Rodrik concluded that the "links between the empirical and theoretical work have never been too strong" (Rodrik 1995: p. 1480). It appears that the boom in endogenous tariff theory over the past two decades has far outstripped the evidence brought to bear on it. My hope is that comparative tariff history like that offered in this paper will help redress the balance, and, in so doing, provoke new thinking on the political economy of tariffs.

This paper relies on a data base documenting average tariffs between 1865 and 1938 for thirtyfive countries. While tariff policy for industrial Europe and the United States has been studied extensively, the rest of the world has not, and of our sample of thirty-five, the majority are from the periphery: ten are from the European periphery; another ten are from Asia and the middle East; and the remaining eight are from Latin America. The advantage of this large panel data base is obvious since it documents an enormous range of tariff policy experience, by period and by country.

What accounts for this immense variety in both cross section and time series? What were the underlying fundamentals driving tariff policy the world around? I think these questions should be at the top of the international economist's agenda. After all, even if we see high and rising tariffs out there in history, we need to know why they were high and rising if this history is to be used to understand the future of globalization in the present century. We have learned a fair amount in this paper: deindustrialization fears were a major determinant of tariff policy in the periphery before World War I, joining grain-invasion fears in the European core; revenue needs were an important determinant of tariff rates in the periphery, and especially for young republics; geography mattered, so that where and when 
the natural protection of distance and topography was conquered by transport technology, tariffs rose to compensate the import competing industries; and, perhaps most important, there was strategic tariff policy behavior at work everywhere after World War I, and much earlier in most young republics forming customs unions.

There is much more to be done to uncover the fundamentals driving world tariff policy in the century before World War II. And while economic historians are doing it, one can only hope that economists will do the same for recent experience. Eli Heckscher would be pleased. 


\section{References}

K. Anderson and Y. Hayami (1986), The Political Economy of Agricultural Protection: East Asia in International Perspective (Sydney: Allen and Unwin).

K. Bagwell and R. W. Staiger (2002), The Economics of the World Trading System (Cambridge, Mass.: MIT Press).

P. Bairoch (1972), "Free Trade and European Economic Development in the $19^{\text {th }}$ Century," European Economic Review 3 (November): 211-45.

P. Bairoch (1989), "European Trade Policy, 1815-191." In P. Mathias and S. Pollard (eds.), The Cambridge Economic History of Europe, vol. III (Cambridge: Cambridge University Press).

R. H. Bates, P. Brock, and J. Tiefenthaler (1991), "Risk and Trade Regimes: Another Exploration," International Organization 45, 1 (Winter): 1-18.

E. Beatty (2001), Institutions and Investment: The Political Basis of Industrialization Before 1911 (Stanford: Stanford University Press).

L. Bértola and J. G. Williamson (2003), “Globalization in Latin America Before 1940.” In V. BulmerThomas, J. Coatsworth and R. Cortés Conde (eds.), Cambridge Economic History of Latin America (Cambridge: Cambridge University Press, forthcoming).

J. N. Bhagwati (2000a), Free Trade Today (Princeton, NJ: Princeton University Press).

J. N. Bhagwati (ed.) (2000b), Going Alone: The Case for Relaxed Reciprocity in Freeing Trade (Cambridge, Mass.: MIT).

C. Blattman, M. A. Clemens, and J. G. Williamson (2002), "Who Protected and Why? Tariffs the World Around 1870-1938." Paper presented to the Conference on the Political Economy of Globalization, Trinity College, Dublin (August 29-31). 
V. Bulmer-Thomas (1994), The Economic History of Latin America Since Independence (Cambridge: Cambridge University Press).

M. A. Centenos (1997), "Blood and Debt: War and Taxation in Nineteenth-Century Latin America," American Journal of Sociology 102 (May): 1565-605.

D. Cleary (1998), "'Lost Altogether to the Civilized World': Race and the Cabanagem in Northern Brazil, 1750-1850," Comparative Studies in Society and History 401 (January): 109-35.

M. A. Clemens and J. G. Williamson (2001), “A Tariff-Growth Paradox? Protection's Impact the World Around 1875-1997," NBER Working Paper 8459, National Bureau of Economic Research, Cambridge, Mass. (September).

M. A. Clemens and J. G. Williamson (2002), "Closed Jaguar, Open Dragon: Comparing Tariffs in Latin America and Asia before World War II," NBER Working Paper 9401, National Bureau of Economic Research, Cambridge, Mass. (December).

J. H. Coatsworth (1988), "Patterns of Rural Rebellion in Latin America: Mexico in Comparative Perspective." In Riot, Rebellion, and Revolution: Rural Social Conflict in Mexico, edited by F. Katz (Princeton: Princeton University Press).

J. H. Coatsworth and J. G. Williamson (2002), “The Roots of Latin American Protectionism: Looking Before the Great Depression," NBER Working Paper 8999, National Bureau of Economic Research, Cambridge, Mass. (June).

J. Conybeare (1983), “Tariff Protection in Developed and Developing Countries: A Cross-Sectional and Longitudinal Analysis," International Organization 37, 3 (Summer): 441-67.

V. Corbo (1992), "Development Strategies and Policies in Latin America: A Historical Perspective," International Center for Economic Growth, Occasional Paper No. 22 (April): 16-48.

M. J. Crucini (1994), "Sources of Variation in Real Tariff Rates: The United States 1900-1940," American Economic Review 84 (June): 732-43. 
C. Diaz-Alejandro (1984), "Latin America in the 1930s.” In R. Thorp (ed.), Latin America in the 1930s (New York: Macmillan): 17-49.

A. Dixit (1987), “Strategic Aspects of Trade Policy.” In T. F. Bewley (ed.), Advances in Economic Theory: Fifth World Congress (New York: Cambridge University Press).

R. H. Dumke (1994), "German Economic Unification in the $19^{\text {th }}$ Century: The Political Economy of the Zolverein," Diskussion Beiträge D-87755, Institut für Volkswirtschaftslehre, Universität der Bundeswehr Müchen (August).

S. Engerman, S. Haber and K. Sokoloff (2000), "Institutions, Factor Endowments, and Paths of Development in the New World," Journal of Economic Perspectives (Summer 2000): 217-32.

A. Gerschenkron (1943), Bread and Democracy in Germany (Berkeley, Calif.: University of California Press).

G. Grossman and E. Helpman (1994), "Protection for Sale," American Economic Review 84, 4 (September): 833-50.

E. F. Heckscher (1919: 1991), “The Effect of Foreign Trade on the Distribution of Income.” Translated and reprinted in H. Flam and M. J. Flanders (eds.), Heckscher-Ohlin Trade Theory (Cambridge, Mass.: MIT).

W. O. Henderson (1962), The Genesis of the Common Market (Chicago: Quadrangle Books).

D. A. Irwin (1997), "Higher Tariffs, Lower Revenues? Analyzing the Fiscal Aspects of the Great Tariff Debate of 1888," NBER Working Paper 6239, National Bureau of Economic Research, Cambridge, Mass. (October).

D. A. Irwin (1998), "Changes in U.S. Tariffs: The Role of Import Prices and Commercial Policies?” American Economic Review 88 (September): 1015-26.

D. A. Irwin (2002), “The Early Trade Policy Experience of the United States, 1789-1820,” unpublished, Department of Economics, Dartmouth College (September 3). 
C. P. Kindleberger (1951), "Group Behavior and International Trade," Journal of Political Economy 59 (February): 30-46.

A. Kraus (1980), Quellen zur Bevölkerungs-, Sozial- und Wirtschaftsstatistik Deutschlands, 1815-1875

(Boppard am Rhein: Boldt).

P. Krugman (1996), Pop Internationalism (Cambridge, Mass.: MIT Press).

N. H. Leff (1982), Underdevelopment and Development in Brazil: vol. 1, Economic Structure and

Change, 1822-1947 and vol. 2, Reassessing the Obstacles to Economic Underdevelopment (London: George Allen and Unwin).

P. H. Lindert (1994), "The Rise in Social Spending, 1880-1930," Explorations in Economic History 31 (January): 1-36.

P. H. Lindert (1998), "Poor Relief Before the Welfare State: Britain versus the Continent 1780-1880," European Review of Economic History 2 (1998): 101-40.

P. H. Lindert and J. G. Williamson (2003), “Does Globalization Make the World More Unequal?” In M. Bordo, A. M. Taylor and J. G. Williamson (eds.), Globalization in Historical Perspective (Chicago: University of Chicago Press).

F. List (1841), Das Nationale System der Politischen Oekonomie (Stuttgart: J. G. Cotta'scher Verlag). A. Maddison (1995), Monitoring the World Economy 1820-1992 (Paris: OECD, Development Centre Studies).

S. P. Magee, W. A. Brock and L. Young (1989), Black Hole Tariffs and Endogenous Policy Theory (Cambridge: Cambridge University Press).

D. Mares, D.(2001), Violent Peace: Militarized Interstate Bargaining In Latin America (New York. Columbia University Press).

G. Márquez (2002), “The Political Economy of Mexican Protectionism, 1868-1911," PhD thesis, Harvard University (March). 
H. P. Marvel and E. J. Ray (1983), “The Kennedy Round: Evidence on the Regulation of International Trade in the USA," American Economic Review 73 (March): 190-7.

H. P. Marvel and E. J. Ray (1987), "Intraindustry Trade: Sources and Effects on Protection," Journal of Political Economy 95 (December): 1278-91.

F. McGillivray, I. McLean, R. Pahre and C. Schonhardt-Bailey (2001), “Tariffs and Modern Political Institutions: An Introduction.” In F. McGillivray et al. (eds.), International Trade and Political Institutions: Instituting Trade in the Long Nineteenth Century (Cheltenham, UK: Edward Elgar).

F. McGillivray (2001), “Trading Free and Opening Markets.” In F. McGillivray et al. (eds.), International Trade and Political Institutions: Instituting Trade in the Long Nineteenth Century (Cheltenham, UK: Edward Elgar).

J. S. Mill (1909), Principles of Political Economy (London: Longmans).

J. V. Nye (1991), “The Myth of Free-Trade Britain and Fortress France: Tariffs and Trade in the Nineteenth Century," Journal of Economic History 51, 1 (March): 23-46.

P. K. O'Brien and S. L. Engerman (1991), "Exports and the growth of the British economy from the Glorious Revolution to the Peace of Amiens.” In B. Solow (ed.), Slavery and the Rise of the Atlantic System (Cambridge: Cambridge University Press).

M. Obstfeld and A. M. Taylor (2003), "Globalization and Capital Markets.” In M. Bordo, A. M. Taylor and J. G. Williamson (eds.), Globalization in Historical Perspective (Chicago: University of Chicago Press).

K. H. O’Rourke (1997), “The European Grain Invasion, 1870-1913,” Journal of Economic History 57 (December): 775-801.

K. H. O'Rourke (2000), “Tariffs and Growth in the Late 19th Century,” Economic Journal 110 (April): 456-83.

K. H. O'Rourke and R. Sinnott (2003), "Migration Flows: Political Economy of Migration and the 
Empirical Challenges," unpublished paper (March).

K. H. O'Rourke and J. G. Williamson (1999), Globalization and History (Cambridge, Mass.: Cambridge University Press).

J. Pincus (1977), Pressure Groups and Politics in Antebellum Tariffs (New York: Columbia University Press).

L. Prados de la Escosura (2003), “The Economic Consequences of Independence in Latin America.” In V. Bulmer-Thomas, J. H. Coatsworth and R. Cortés Conde (eds.), Cambridge Economic History of Latin America (Cambridge: Cambridge University Press, forthcoming).

F. Rodríguez and D. Rodrik (2001), “Trade Policy and Economic Growth: A Skeptic's Guide to the Cross-National Evidence," in B. Bernanke and K. S. Rogoff (eds.), Macroeconomics Annual 2000 (Cambridge, Mass.: MIT).

D. Rodrik (1995), “Political Economy of Trade Policy.” In G. M. Grossman and K. Rogoff (eds.), Handbook of International Economics, Volume 3 (Amsterdam: Elsevier): 1457-94.

R. Rogowski (1989), Commerce and Coalitions: How Trade Effects Domestic Political Arrangements (Princeton, N.J.: Princeton University Press).

G. von Schmoller (1904), Grundriss der Allegemeinen Volkswirtschaftslehre (Leipzig: Duncker and Humblot).

A. Smith (1776: 1976), An Inquiry into the Nature and Causes of the Wealth of Nations (Oxford: Clarendon Press).

W. Stolper and P. Samuelson, "Protection and Real Wages," Review of Economic Studies 9 (1941): 5873.

F. W. Taussig (1892), Tariff History of the United States (New York: The Knickerbocker Press).

A. Taylor (1998), “On the Costs of Inward-Looking Development: Price Distortions, Growth, and Divergence in Latin America," Journal of Economic History 58 (March): 1-28. 
J. G. Williamson (1998), "Globalization, Labor Markets and Policy Backlash in the Past," Journal of Economic Perspectives 12 (Fall): 51-72.

J. G. Williamson (2002), "Two Centuries of Globalization: Backlash and Bribes for the Losers," WIDER Annual Lecture, Copenhagen (September 5).

G. Wright (1990), "The Origins of American Industrial Success, 1879-1940," American Economic Review 80 (September): 651-68. 


\section{Table 1 \\ Tariff Impact on GDP per capita Growth, Core vs Periphery 1870-1913}

\begin{tabular}{lc}
\hline In GDP/capita & 0.12 \\
& 1.23 \\
In Own Tariff & 0.36 \\
& 2.28 \\
(European Periphery & -0.53 \\
dummy) x (In tariff rate) & -2.48 \\
(Latin America & -1.04 \\
dummy) x (In tariff rate) & -3.22 \\
(Asia dummy) x & 0.20 \\
(In tariff rate) & 0.79 \\
Euro Periph dummy & 1.12 \\
& 2.05 \\
Latin America dummy & 3.36 \\
& 3.39 \\
Asia dummy & -0.50 \\
& -0.95 \\
Constant & -0.43 \\
& -0.54 \\
\hline Country Dummies? & \\
Time Dummies? & $\mathrm{No}$ \\
R-squared & $\mathrm{No}$ \\
Adj. R-squared & 1,180 \\
& 0.0516 \\
& 0.0451 \\
& \\
& \\
& \\
&
\end{tabular}

Notes: $t$-statistics are in italics. Dependent variable is 5-year overlapping average growth rates.

Source: Coatsworth and Williamson (2002), Table 1. 
Table 2. Tariff Rate Determinants the World Around 1870-1938

Dependent variable: In Own Tariff

Includes AR(1) Baltagi-Wu (TS) or Cochrane-Orcutt (CS) serial correlation correction

Specification

TS, country RE

CS, year dummies

Years

Countries

1870-1938 1870-1938 1870-1938 1870-1938 1870-1938

In Export Share

$$
\text { All }
$$

All

All

All

All

19381870

1938 1870-1938 1870-1938 1870-1938

In

In

In GDP pe
capita

In Population

$-0.0285-0.0832$

$-0.0609$

$(-1.36) \quad(-3.02)$

$(-2.30)$

-0.0463
$(-2.07)$

$-0.0924$

$-0.0397$

$-0.1412-0.2227$

$-0.1745$

$(-2.40)$

$-2.86)$

$(-2.28)$

$-0.1810$

$(-3.32)$

$(-1.37)$

$-0.0645 \quad-0.0601$

All

All All

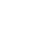

In Partner

Tariffs

$-0.1084-0.1716$

$(-2.50) \quad(-3.35)$

$\begin{array}{lll}-0.1441 & -0.1172 & -0.1721\end{array}$

$0.2490 \quad 0.2507$

$(-2.81)$

$(-258)$

$(-3.38)$

$-0.1025$

$(-1.67)$

$(-1.60)$

$-0.0539 \quad-0.0753$

$(-9.06)$

0.2992

$0.2246 \quad 0.2526$

$(-1.48)$

$-0.1445$

$-0.1228$

$(-1.80)$

$(-2.02)$

In Effective

$-0.0735-0.1072$

$(-8.45)$

$(-7.54)$

$(-6.67)$

$-0.122$

$(-1.44)$

$(-1.24)$

$-0.1439-0.1435$

Distance

$(-4.86)$

$-0.1072-0.1267$

$-0.0584-0.1086$

$(-2.85)$

$-0.0545$

$(-2.00)$

$(-1.45)$

In Railway

Mileage

0.0354

$(-4.95)$

$(-5.97)$

$(-3.76)$

-0.1086
$(-5.02)$

$-0.0440$

$(-1.22)$

$(-0.84)$

$(-1.12)$

$-0.1302$

$-0.0504$

$(-3.38)$

0.0639

0.0579

$(-3.76)$

$-0.0169$

$-0.0983$

$-0.0338$

(-3.00)

$(-1.00)$

In Schooling

0.1640
$(-4.02)$

$(-2.25)$

$(-1.98)$

0.0347

0.0590

$(-0.74)$

$(-1.82)$

$(-0.60)$

$\begin{array}{ll}-0.0648 & -0.0953\end{array}$

$(-4.02)$

$-0.0560$

$-0.0573$

(-3.41)

$(-2.08)$

0.0055

$-0.0644$

$-0.0514$

$(-1.76)$

$(-1.73)$

In Urbanization

$0.0478 \quad 0.0198$

$(-2.13) \quad(-0.30)$

$(-0.84)$

$(-4.30)$

$-0.0416$

$(-0.80)$

$(-1.53)$

$(-1.28)$

$-0.0309 \quad-0.0616$

$\begin{array}{ll}-0.0309 & -0.0616 \\ (-1.29) & (-1.48)\end{array}$

Federal

$\begin{array}{lll}0.0013 & 0.0462 & 0.0235 \\ (-0.02) & (-2.10) & (-0.36)\end{array}$

0.0672

$\begin{array}{llll}0.0212 & 0.0190 & 0.0042 & 0.0219\end{array}$

$\begin{array}{llll}(-0.93) & (-0.84) \quad(-0.56) \quad(-0.94)\end{array}$

Colony

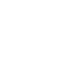

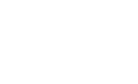

Inflation

Inflation Squared

$+2$

In Terms of

Trade Index

.

Constant

N

Groups

Avg. obs / group

R-squared overall

DW original

DW transformed

\begin{tabular}{rr} 
& \\
& \\
& \\
& \\
& \\
& \\
& \\
2.7797 & 5.8022 \\
$(-4.75)$ & $(-7.80)$ \\
& \\
2,138 & 1,169 \\
35 & 30 \\
61.1 & 39 \\
0.224 & 0.271 \\
0.222 & 0.242 \\
& \\
\hline
\end{tabular}

\begin{tabular}{|c|c|c|c|c|c|c|c|}
\hline $\begin{array}{r}-0.0004 \\
(-1.45)\end{array}$ & & $\begin{array}{r}-0.0005 \\
(-1.46)\end{array}$ & & & $\begin{array}{r}-0.0004 \\
(-0.90)\end{array}$ & & $\begin{array}{r}-0.0003 \\
(-0.69)\end{array}$ \\
\hline $\begin{array}{l}0.0000 \\
(-2.45)\end{array}$ & & $\begin{array}{l}0.0000 \\
(-1.77)\end{array}$ & & & $\begin{array}{l}0.0000 \\
(-0.44)\end{array}$ & & $\begin{array}{l}0.0000 \\
(-0.52)\end{array}$ \\
\hline & $\begin{array}{l}0.0798 \\
(-2.22)\end{array}$ & $\begin{array}{l}0.1219 \\
(-2.68)\end{array}$ & & & & $\begin{array}{l}0.1037 \\
(-2.55)\end{array}$ & $\begin{array}{l}0.1371 \\
(-2.66)\end{array}$ \\
\hline $\begin{array}{l}5.4237 \\
(-7.45)\end{array}$ & $\begin{array}{l}2.6333 \\
(-4.28)\end{array}$ & $\begin{array}{l}5.1674 \\
(-6.68)\end{array}$ & & & & & \\
\hline $\begin{array}{r}1,300 \\
35 \\
37.1\end{array}$ & $\begin{array}{r}1,951 \\
35 \\
55.7\end{array}$ & $\begin{array}{r}1,169 \\
30 \\
39\end{array}$ & 2,067 & 1,116 & 1,238 & 1,889 & 1,116 \\
\hline 0.25 & 0.251 & 0.266 & 0.144 & 0.203 & 0.195 & 0.149 & 0.211 \\
\hline 0.251 & 0.227 & 0.245 & $\begin{array}{l}0.083 \\
1.972\end{array}$ & $\begin{array}{l}0.107 \\
1.979\end{array}$ & $\begin{array}{l}0.115 \\
1.948\end{array}$ & $\begin{array}{l}0.083 \\
1.982\end{array}$ & $\begin{array}{l}0.111 \\
1.987\end{array}$ \\
\hline
\end{tabular}

$\mathrm{t}$-statistics are in parentheses below each coefficient estimate. War years (1914-1918) omitted. Schooling is measured as the number of people per 10,000 below the age of 15 who are enrolled in primary school.

Source: Blattman, Clemens and Williamson (2002), Table 3 (revised). 


\section{Table 3}

\section{Size and Administration Efficiency: The Zollverein 1818-1836}

Custom Administration
Costs/Customs Revenues

Zollverein (1836)

Prussia (1818)

Bavaria (1826)

Wurttemberg (n.d.)

Kurhessen (n.d.)

Hessen-Darmstadt (n.d.)
0.147

0.175

0.250

0.430

1.000

1.000
Kuehne's

Ratio

0.130

0.200

0.240

0.470

1.130

1.060
Area

(meilen)

9569

5104

1337

354

166

153

Source: Dumke (1994), Table Vlb, p. 33 and Table VI, p. 55. Note: An old German meile equal 4.68 English statute miles. 
Figure 1: Unweighted World Average Own Tariff, 35 Countries, \%

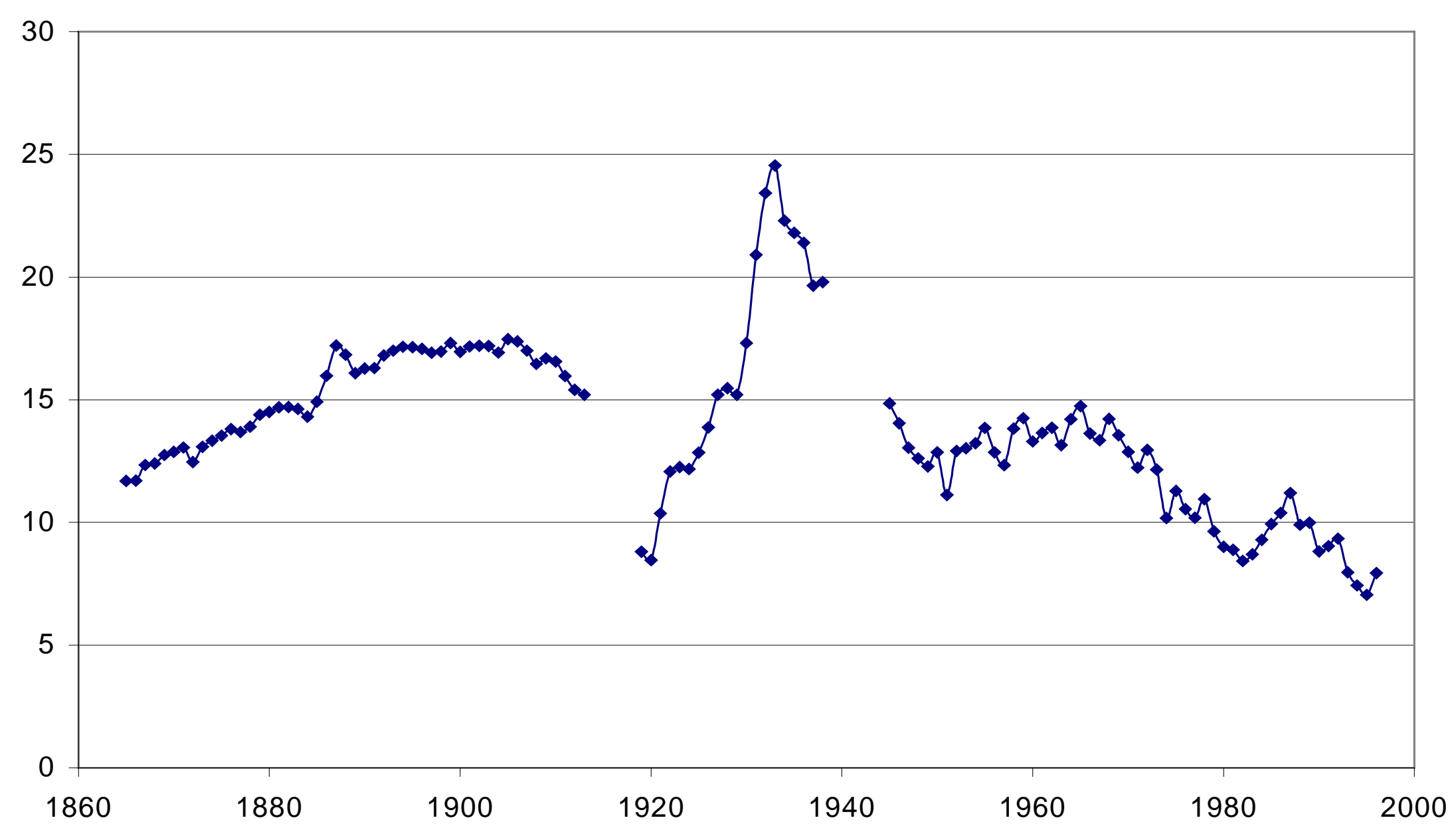

Source: Blattman, Clemens and Williamson (2002), Figure 1. 


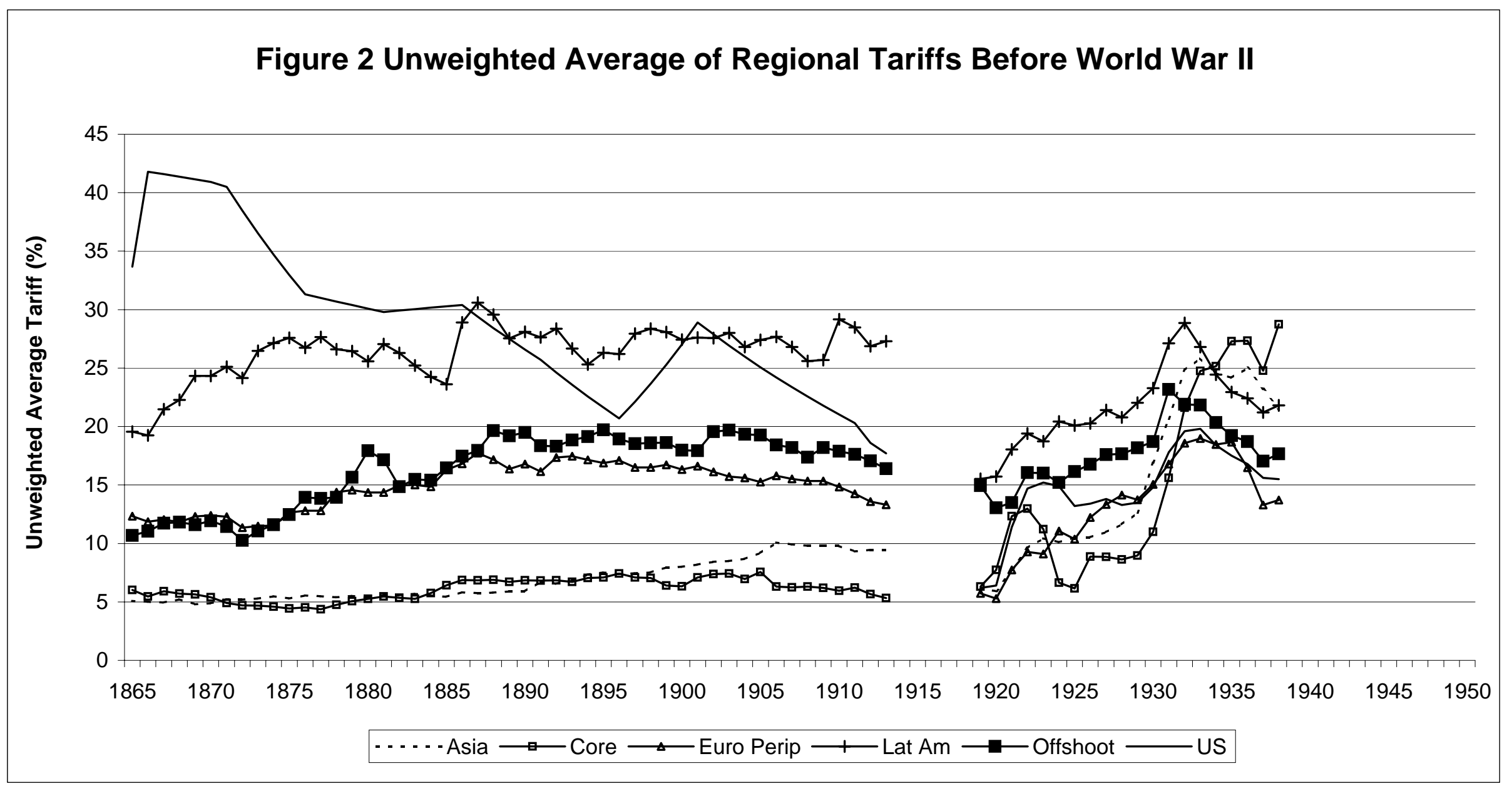

Source: Coatsworth and Williamson (2002), Figure 2. 
Figure 3 Average Tariff Rates in the United States 1790-1836

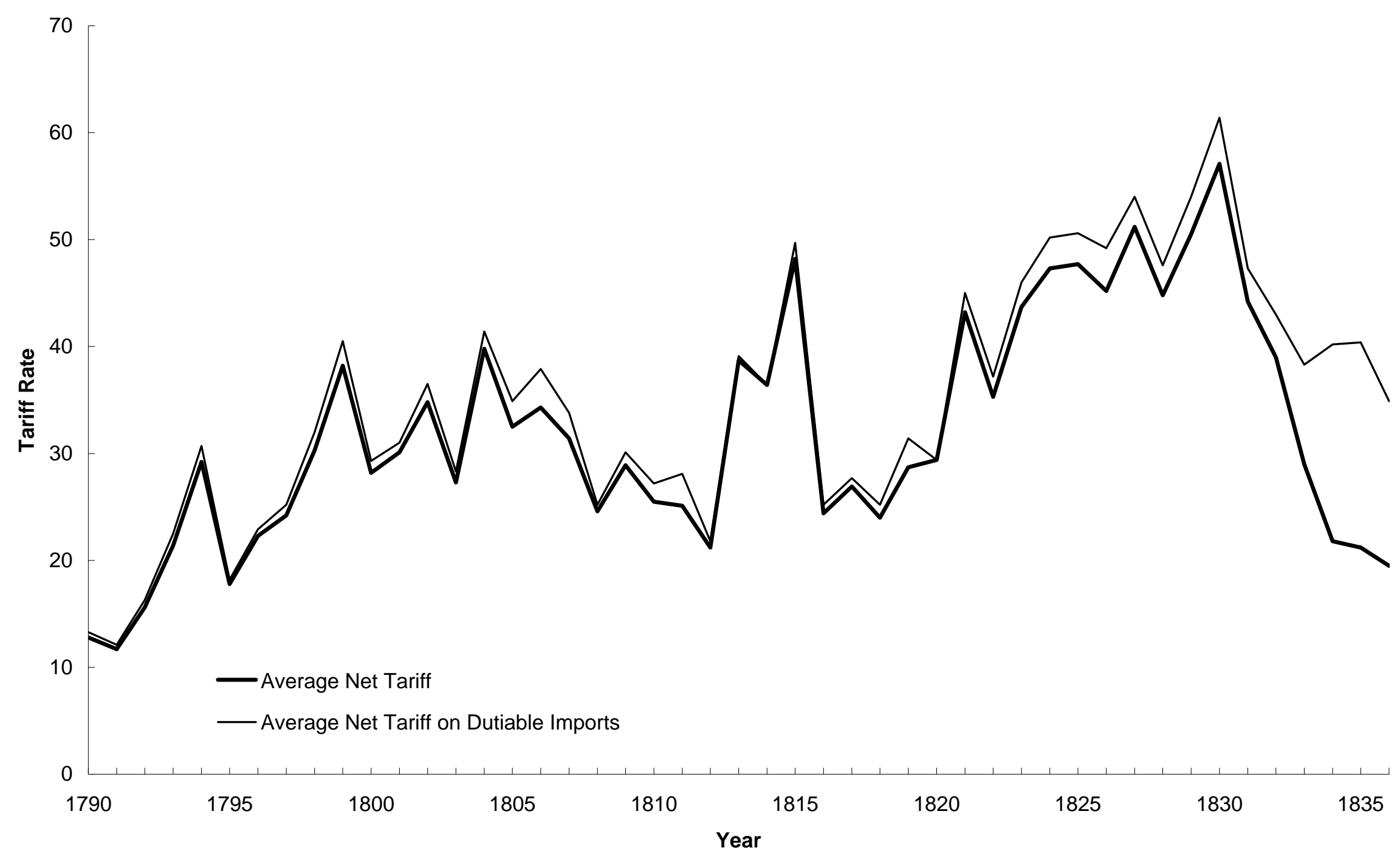

Source: Irwin (2000), Table 1 and Figure 1, pp. 32 and 36. 
Figure 4 Fiscal Scale Economies in the Zollverein

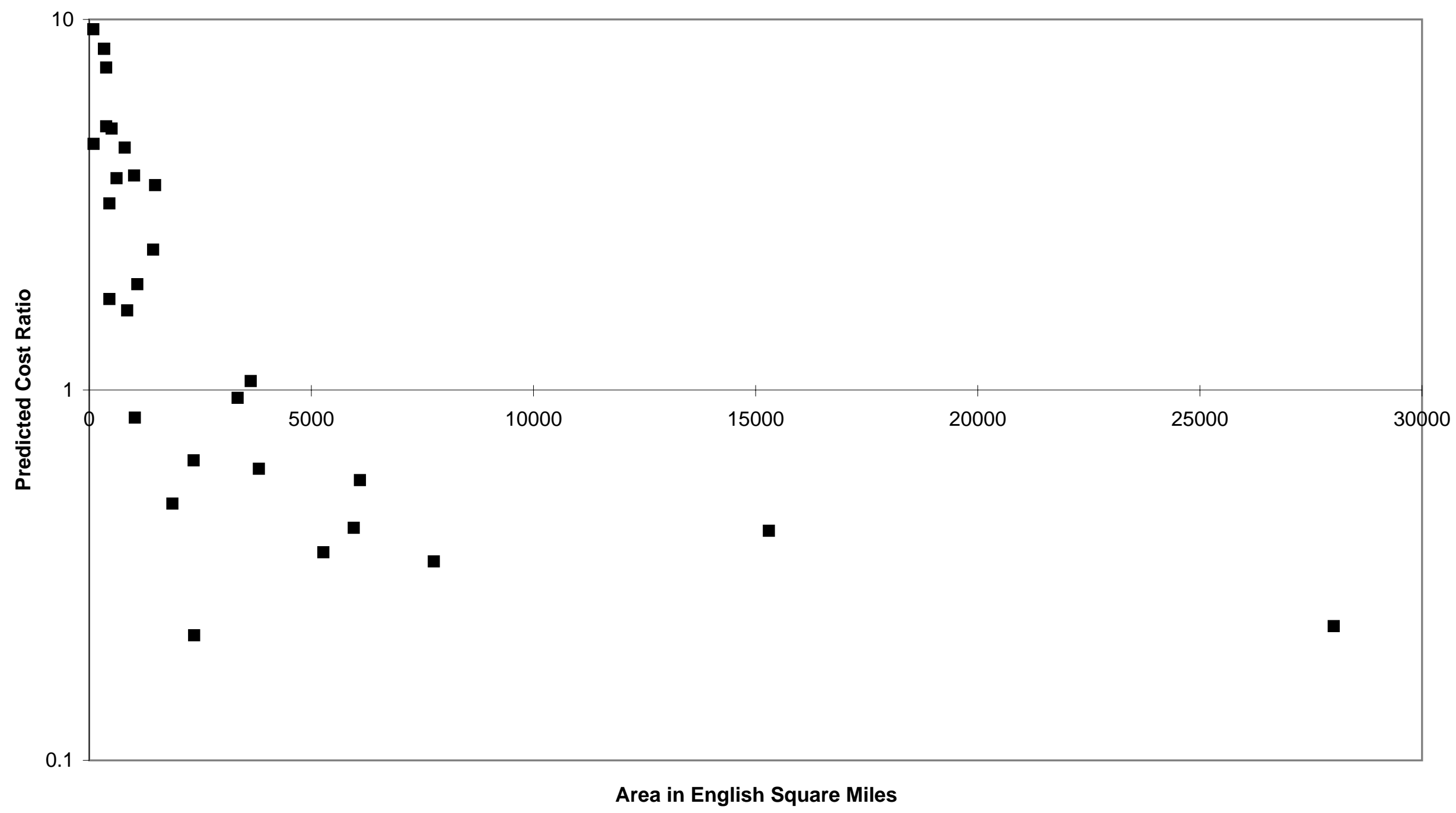

